NBER WORKING PAPER SERIES

POST-WAR CHANGES IN THE AMERICAN
FINANCIAL MARKETS

Benjamin M. Friedman

Working Paper No. $\underline{458}$

NATIONAL BUREAU OF ECONOMIC RESEARCH 1050 Massachusetts Avenue

Cambridge MA 02138

February 1980

This essay, prepared for the National Bureau of Economic Research project on Post-War Changes in the Amercian Economy, is part of the National Bureau's research on Financial Markets and Monetary Economics. The author is grateful to Christopher Piros and Michael Burda for research assistance; to James Duesenberry, John Lintner, Sanford Rose, William Silber, Stephen Taylor and James Tobin for helpful discussions and comments on an earlier draft; and to the National Bureau and the Alfred P. Sloan Foundation for research support. Any opinions expressed are those of the author and not those of the National Bureau of Economic Research. 
Post-War Changes in the American Financial Markets

\section{$\underline{\text { ABSTRACT }}$}

This essay surveys developments in the American financial markets since World War II, with particular attention to changes that have occurred either between the pre-war and post-war years or within the last several decades. The primary emphasis is on the interaction between the financial markets and the nonfinancial economy, in the sense of the demands that the nonfinancial economy has placed on the financial markets and the ways in which the financial markets have responded to these demands. In addition, much of this essay focuses on the evolving role of government in the financial markets, and on changes that it has brought about.

Three major trends emerge as predominant during the post-war years. First, a sustained rise of private debt financing, including the borrowing of both businesses and individuals, has almost exactly matched the decline of outstanding federal government debt relative to nonfinancial economic activity. Second, the economy's reliance on financial intermediaries has continued to increase; together with a series of innovations, the further advance of intermediaries has reduced barriers and frictions interfering with efficient capital allocation. Third, in contrast to the sharp relative decline of its role as a direct borrower, the federal government has widely expanded its activities in guaranteeing and intermediating the private sector's debt, as well as in regulating private financial transactions.

Benjamin M. Friedman Dëpartment of Economics Littauer Center 127 Cambridge, Massachusetts 


\title{
POST-WAR CHANGES IN THE AMERICAN FINANCIAL MARKETS
}

\author{
Benjaniin M. Friedman* \\ Harvard University
}

Financial markets are an integral part of the modern economy. The many and varied activities of financial markets both mirror and induce events in the economic system at large. Only rarely, however, do they serve as ends in themselves. Instead, they facilitate earning and spending, saving and investing, accumulating and retiring, transferring and bequeathing - all activities at the core of economic life. In principle people could do all of these things without financial markets. In practice well functioning financial markets enable people to do them more efficiently, and few economic events take place without their financial counterparts. Financial markets in fact constitute an essential vehicle through which the millions of different participants in the nonfinancial economy continually interact with one another.

The needs and resources, and the objectives and concerns, that people bring to financial transactions are always changing. Greater preferences for home ownership, reduced concerns for providing for one's own or one's children's future, or the desire to take advantage of a new production technology, will change what people seek from the financial markets and hence will change what takes place there. New initiatives of public policy, and the persistent advance in the technology (especially communications technology) on which the financial markets rely in conducting their own 
business, can also be the source of financial market change. Moreover, because every transaction has two sides - a buyer and a seller, or a borrower and a lender - changes in what some people bring to the financial markets necessarily imply changes in what others find there. Hence financial markets act to transmit, not just absorb, the chain of events that originates in the nonfinancial economy, and in so doing they also importantly influence these events. Observing the financial markets therefore provides an additional perspective for understanding nonfinancial developments, even if the more basic origin of those developments is itself entirely nonfinancial.

The experience of the American finarcial markets in the era since World war II, when compared to the corresponding pre-war experience, presents both continuities and contrasts. A time traveller from 1940, or even 1900, would probably feel more nearly at home on first disembarking in. the financial markets than in most other major arenas of 1980 American economic activity. He would immediately recognize major classes of financial market participants and their chief activities, including banks taking deposits and making loans, insurance companies spreading risk and investing in securities, corporations borrowing to finance capital spending, and individuals both saving for their retirement and borrowing to buy houses. The chief items issued and exchanged in these markets are still currency and deposits, stocks and bonds, bills and IOJ's. Even the principal financial events that are news today - a large government financing, or an episode of tight money, or a stock market rally, or a bulge in the corporate underwriting calendar - are happenings that attracted attention forty and in some cases eighty years ago. 
Much of this immediate familiarity, however, would pertain to the surface only. Behina the sameness of the players and their working vocabulary, in many respects the American financial markets are performing (or misperforming) their various functions differently today than they did years ago. Some changes have reflected the changing requirements placed on the financial markets by the nonfinancial economy, while others have reflected government actions, and in a few cases the primary inpetus to change has been innovation within the financial markets themselves. The pace of change has not been uniform either. Some differences between today's financjal markets and those of forty years ago represent a contrast between the pre-war years and the post-war period as a whole, but others represent instead the ongoing process of change that has occurred throughout the post-war era.

The object of this essay is to gain an overview of developments in the American financial markets since World War II, with particular attention to changes that have occurred either between the pre-war and post-war years or within the past several decades. Inevitably such an effort must be selective. The primary emphasis here is on the interaction between the financial markets and the nonfinancial economy, in the sense of the demands that the nonfinarcial economy has placed on the financial markets and the ways in which the financial markets have responded to these demands. In addition, much of this essay focuses on the evolving role of government in the financial markets, and on the changes that it has brought about. Questions pertaining to the internal organization of financial markets and financial institutions, and to financial innovations per se, are also important; but they receive less attention here nonetheless. 
Section I briefly sets the background for this analysis by reviewing some significant differences in the underiying economic clinate between the pre-war and post-war periods. Section II examines j.n detail the changes that have taken place in the financing of the economy's ronfinancial activity. Here the dominant trend of the post-war period has been the increasing tendency toward an economy financed by private rather than public debt. Section III explores changes in the ways in which financial markets have met these needs, with particular attention to the role of financial intermediaries and changes in patterns of intermediation. The dominant trend of post-war developments in this regard has been a continuing increase in the economy's reliance on financial intermediation which, together with a series of innovations, has reduced barriers and frictions interfering with efficient capital allocation. Section IV focuses on changes in the role of government in the financial markets. The major expansion of the federal government's financial activities during the post-war years has been in guaranteeing and intermediating the private sector's debt, as well as in regulating private financial transactions. In addition, section IV provides a brief qualitative account of the ways in which both the conduct of monetary policy and its perception by financial market participants have evolved during the post-wax period. Finally, section $V$ summarizes the principal conclusions of this survey and re-emphasizes the interconnections among them. 


\section{Changes in the Underlying Economic Climate}

Although the focus of this essay is on changes in financial markets, it is helpful to begin by noting briefly a few of the major changes that have taken place in the underlying climate of nonfinancial economic

activity. ${ }^{l}$ Three such changes are of particular relevance for understanding what has happened in the financial market.s.

First, the American ecoromy in the post-war era nas enjoyed much greater stability and prosperity than in the earlier decades of this century. Despite widespread early fears that "secular stagnation" would follow the country's demobilization after world war II, real output and incomes in the American economy in the post-war era turned out to be both stronger and steadier than in the corresponding pre-war experience. As the first two columns of Table 1 show, the post-war years - especially the 1960 s - have displayed not only greater economic growth on average (as measured by real gross national product) but also a smaller variability of that growth. ${ }^{2}$ The pattern of the business cycle, indicated in Table 2 by the peak-to-trough decline in real gross national product for the thirteen cycles that occurred during the past sixty years, also highlights the increased stability of the post-war period. On the whole, the economy's downturns have been both shorter and shallower. ${ }^{3}$ Furthermore, not only has the economy during the post-war period experienced less severe recessions on average, but until 1973 the trend appeared to be toward progressively less severity. After the recessions of 1953-54 and 1957-58, a decade and a half elapsed before another downturn amounted to as much as half of their fairly modest magnitudes.

This enhanced stability of the real economy has both affected and been 
Table 1

\section{Measures of U.S. Economic Conditions}

\begin{tabular}{|c|c|c|c|c|c|c|}
\hline & Growth & eal GNP & Change & ty Prices & Consume & $=\mathrm{In}$ \\
\hline & Mean & S.D. & Mean & S.D. & Mean & S.D. \\
\hline $911-1920$ & 1.7 & 5.2 & -1.1 & 9.6 & 8.1 & 7.4 \\
\hline $921-1930$ & 3.1 & 7.9 & 11.5 & 17.0 & -1.7 & 4.0 \\
\hline $931-1940$ & 2.6 & 8.8 & -2.1 & 27.3 & -1.6 & 5.0 \\
\hline $941-1950$ & 4.9 & 8.2 & 6.3 & 14.8 & 5.6 & 4.8 \\
\hline $951-1960$ & 3.3 & 3.2 & 12.4 & 12.6 & 2.1 & 2.3 \\
\hline $961-1970$ & 4.0 & 2.2 & 4.6 & 10.1 & 2.8 & 1.8 \\
\hline $971-1978$ & 3.4 & 3.1 & 2.6 & 13.6 & 6.7 & 2.5 \\
\hline
\end{tabular}

Notes: Data are means and standard deviations, in percent per annum.

Sources: U.S. Department of Commerce, Standard and Poor's and U.S. Bureau of Labor Statistics 
Table 2

Timing aid Severity of U.S. Business Cycle Downturns

\begin{tabular}{lll} 
Peak & \multicolumn{1}{c}{ Trough } & Decline in Real GNP \\
\hline $1918: Q 3$ & $1919: Q 1$ & 3.68 \\
$1920: Q 1$ & $1921: Q 3$ & 8.78 \\
$1923: Q 2$ & $1924: Q 3$ & 0.28 \\
$1926: Q 3$ & $1927: Q 4$ & 0.18 \\
$1929: Q 3$ & $1933: Q 1$ & 29.48 \\
$1937: Q 2$ & $1938: Q 2$ & 4.18 \\
$1945: Q 1$ & $1945: Q 4$ & 15.98 \\
$1948: Q 4$ & $1949: Q 2$ & 1.48 \\
$1953: Q 2$ & $1954: Q 2$ & 3.38 \\
$1957: Q 3$ & $1958: Q 1$ & 3.28 \\
$1960: Q 1$ & $1960: Q 4$ & 1.28 \\
$1969: Q 3$ & $1970: Q 4$ & 1.18 \\
$1973: Q 4$ & $1975: Q 1$ & 5.78
\end{tabular}

Notes: Peak and trough dates from National Bureau of Economic Research reference cycles.

Real GNP decline in first seven recessions shown based on annual National Income and Product Accounts data (comparison of 1946 over 1944 for 1945 recession).

Real GNP decline in last six recessions shown based on quarterly National Income and Product Accounts data. 
reflected by financial values. As the next two columns of rable 1 show, equity prices in the post-war period, especially until the 1970s, have been less variable than in the pre-war period. There have also been fewer nonfinancial corporate bankruptcies since World War II. There have been far fewer bank failures, and - until 1974 - essentially no failures at all of large banks.

The realization that the post-war Americar economy had entered an era of stability and prosperity, instead of returning to the years of chaos and depression, gradually altered both business and consumer thinking in. important ways. In addition, the emergence of the United States as the world's dominant military superpower, with attendent responsibilities and privileges in the political and economic spheres, only contributed further to the sense of confidence and expanding horizons. The resulting new perceptions of growth opportunities and new attitudes toward risk bearing in turn played a major role in bringing about the changing patterns of corporate finance and personal saving that are the subject of section II below, as well as some aspects of the changing patterns of financial intermediation that are the subject of section III.

A secona major feature of the post-war American economy that has importantly affected developments in the financial markets has been price inflation. Whether by cause or by accident, the economy's newfound real prosperity and stability did not come without costs, and among these costs the most readily apparent to almost all of the economy's participants has been the acceleration and increasing volatility of inflation during the second half of the post-war period (see the next two columns of Table 1). The post-war period at first brought an improvement in the stability of 
prices as well as real incomes, as the rapid and volatile inflation of the imnediate post-war years gave way to price movements that were on balance both slower and steadier, especially in the early 1960s. The improvement, however, proved only temporary. Beginning in the mid 1960 s prices land wages) rose more rapidly, leading in time to two episodes of double-digit inflation in the 1970s. Moreover, the faster average rate of price increase during the most recent decade has itself been more volatile.

It is not the purpose of this essay to analyze the reasons for the accelerating post-war American inflation. The focus here is rather on the effects of this new development on the financial markets. Because the greatest acceleration of inflation has come only within the past decade, many key substantive questions about the effects of inflation remain unresolved. Even so, it seems clear already that scre of the important financial changes discussed in sections II and III beiow have been due at least in part to individuals' and businesses' increasing awareness of inflation per se, as well as to the rising average irterest rate levels that inflation has brought. In addition, several changes in the role of government discussed in section IV have also come about largely as a result of either or both of inflation and high nominal interest rates.

Finally, a third feature of the post-war American economic climate that is useful to bear in mind in analyzing this era"s financial market changes is the shifting character of the international equilibrium for disequilibrium). From the beginning of World War I carward, the Western world's international economic balance was highly precäious, and international mechanisms were important in propagating economic disturbances as well as in heightening their severity. ${ }^{4}$ In the early years after world war II, 
it looked as if the worid economy was at last - or, in the opinion of some who recalled conditions before World war I, again - relatively free from this source of instability. After world war II the worid had accepted a de facto dollar standard; and it maintained this convenience even after the return to convertibility of key European currencies in 1958. In addition, until the early 1960s the recovering European economies continually sought both more dollars and more American goods, so that the United States enjoyed not only a strong balance of payments but also the confidence that came from knowing that other countries would gladly absorb dollars in payment for their goods if the American payments balance were not in balance. This situation changed as the post-war period advanced. America's trading partners increasingly became competitors, and tough competitcrs at that. Balance-of-payments surpluses changed to deficits. Discussions of how the United States could satisfy the familiar "dollar shortage" disappeared, to be replaced by questions of what, if anything, the United States could do to relieve the "dollar overhang." In the 1970s volatility in the foreign exchange markets again became a major concern, this time with a weak rather than a strong dollar as the center of attention. Questions. about the futire of the dollar's role in international trade and finance became widespread, especially after the abandonment of dollar-gold convertibility in 1971 and the gradual move to a de facto system of "floating but managed" exchange rates during the next several years. The effective cartelization of the world oil supply in 1973 brought a new wave of payments imbalances and highly skewed accumulations of international reserves, this time far greater in magnitude than any recent experience. On balance, the trend toward ever greater stability in the international economic environment in the first half of the post-war period reversed itself in the second half, 
although even in the 1970s the situation is far from what it was in the inter-war years, and the continuing presence of institutions like the International Monetary Fund provide a measure of safety that was not there before. This advance and then retreat in the stability of the international economic system, and simultaneously in the strength of the American position in it, have also helped to mold a number of the major shanges that have taken place in the American financial markets during this period.

In sum, real economic stability and prosperity, accelerating price inflation, and a more stable but somewhat deteriorating international equilibrium have lain behind much of the development of the Anerican financial markets in the post-war era. Just within the past half decade, however, public confidence in the continuation of the first of these three factors has weakened noticeably. In part this reduced confidence has reflected the growing awareness of inflation and international events, together with a mounting sentiment that these processes must not continue unabated. To whatever extent conditions fostering inflation and a weak dollar had been a source of rapid economic growth, the public has inferred that actions taken to curb them will probably trim the economy's average real performancs too. The unanticipated magnitude of the 1973-75 recession, coming as it did after two decades of damping of the economy's business cycle, also exerted a major impact on people's thinking. So too did the series of oil price increases imposed by the cartel. To whatever extent the reliance on inexpensive and plentifully available energy supplies had been a source of rapid growti, the public has feared that both price and quantity actions taken by the foreign oil producers will limit and disrupt future growth. Even simple extrapolations of economic growth on the basis of purely 
domestic developments like labor force and productivity also suggested slower growth ahead, since by the 1970 s the post-war baby boom had matured, the birth rate had fallen sharply, and the trend rise in productivity had suffered at least one downward shift. 5

Moreover, economic events have probably not been the sole cause of the decline in confidence in America's economic prospects that has set in during the 1970s. Loss of the Vietnam War, apparent erosion of American influence in world affairs, failure to meet domestic social objectives set in the 1960s, increased emphasis on pollution and other intangible costs typically associated with the economic growtin process, the political trauma of watergate - all contributed to the feeling, widely reported in surveys of business and consumer opinion, that the future looked less brigit than the post-war past had been.

The chief reason why it is useful to emphasize here this most recent apparent shift in attitudes toward the ration's economic climate and prospects is that it provides a clear warning against projecting, as a forecast, any simple continuation of the post-war financial developments described in the remainder of this essay. Within only a decade - a relatively brief interval in the context of the overview attempted here the American public has sharply changed its perception of the stable growth and prosperity that has been perhaps the central feature of their economy's post-war experience. Events may yet prove them right or wrong, but financial behavior responds powerfully to attitudes and perceptions as well as realities. Especially for changes in financial markets, analyzing the past is not equivalent to predicting the future. 
II. Changes in the Financing of Economic Activity

Individuals, businesses and governments sometimes engage in financial transactions directly with one another, although more often one or more intermediaries stand between them. Nevertheless, because the needs of nonfinancial entities to borrow and lend, to issue liabjlities and hold assets, to render and receive payments, constitute the essential raison d'etre of financial markets, in assessing changes in financial markets over a long period of time it is useful to begin by abstracting from the financial intermediation process and directly examining changes in the liability issuing and asset holding behavior of the economy's nonfinancial participants.

\section{A. The Post-War Rise of the Private Debt Economy}

The single development in the American financial markets since world War II that has been most striking from this perspective has been tine rise of the private debt economy. Individuals and especially businesses have almost continually increased their degree of reliance on debt in relation to their basic nonfinancial activity. Corporations have relied more on both negotiated loans and market debt issues, in comparison to equity either issued externally or retained internally, to finance their ownership of productive assets and working capital. Individuals have relied more on mortgage credit to finance their houses, and on consumer credit to finance their ownership of durables and even their current consumption. As a result, the indebtedness of the American economy's private sector has risen substantially.

It is essential to ask at the outset whether this pervasive increase in private indebtedness that has taken place during the post-war period has 
also represented a change in the nonfinancial economy's total propensity to issue debt liabilities (and hold debt assets). The arswer is a straightforward negative. The total amount of debt issued by nonfinancial borrowers in the American economy has in fact remajned remarkably stable, in relation to economic activity, throughout the post-war period. ${ }^{6}$ Hence the great rise in private debt has mirrored a substantial decline, relative to economic activity, in public debt. Although state and local governments have increased their debt somewhat, an enormous decline lagain, relative to economic activity) in the federal government's outstanding debt has predominated. Hence the post-war rise of the private debt economy has come largely as the counterpart of a falling off of federal indebtedness.

Figure 1 and Table 3 indicate the gencral dimensions of the post-war movement to private debt. ${ }^{7}$ Figure 1 plots, for the years $1918-78$, the total outstanding credit market debt issued by the econony's nonfinancial borrowers, scaled as a percentage of nonfinancial economic activity as measured by gross national product. The figure also plots the respective components of this total debt ratio according to major categories of nonfinanciall borrowers in the economy: the federal government, state and local governments, businesses, and households. Table 3 presents for closer inspection the underlying data for the post-war years, further distinguishing between corporate and noncorporate businesses and also including, as a memorandum item, debt issued in American markets by foreign borrowers. 8

The key aspect of the American nonfinancial economy's use of financial markets that stands out sharply in Figure 1 is the relative stability of its total debt outstanding despite the wide variation of the several components that together comprise the total. Apart from a one-time adjustment 


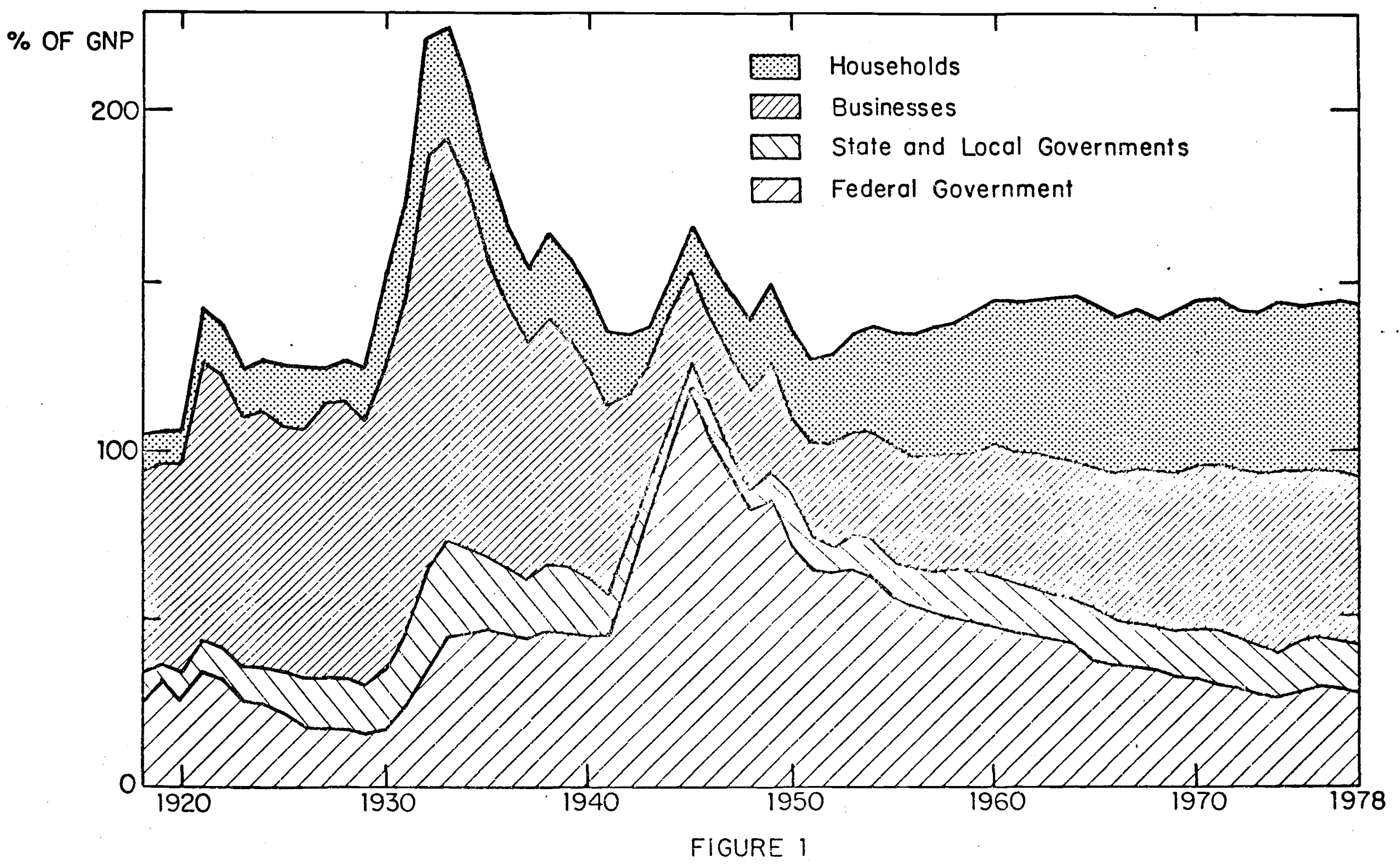

OUTSTANDING DEBT OF U.S. NONFINANCIAL BORROWERS 
Table 3

Outstanding Debt of U.S. Nonfinancial Borrowers

\begin{tabular}{|c|c|c|c|c|c|c|c|}
\hline & Total & $\begin{array}{l}\text { Fed. } \\
\text { Govt. }\end{array}$ & $\begin{array}{c}\text { State } \\
\& \\
\text { Local } \\
\text { Govt. }\end{array}$ & $\begin{array}{l}\text { Busi- } \\
\text { ness } \\
\text { Corps. }\end{array}$ & $\begin{array}{l}\text { Other } \\
\text { Busi- } \\
\text { nesses }\end{array}$ & $\begin{array}{l}\text { House- } \\
\text { holds }\end{array}$ & $\begin{array}{l}\text { Memorandum: } \\
\text { Foreign }\end{array}$ \\
\hline 1946 & 155.8 & 103.5 & 7.0 & 22.4 & 7.0 & 16.0 & 3.6 \\
\hline 1947 & 145.7 & 90.6 & 6.9 & 23.3 & 7.0 & 18.0 & 5.0 \\
\hline 1948 & 138.4 & 81.0 & 7.2 & 23.7 & 7.0 & 19.6 & 5.2 \\
\hline 1949 & 149.5 & 84.9 & 8.4 & 25.2 & 7.6 & 23.5 & 5.4 \\
\hline 1950 & 133.3 & 70.8 & 8.2 & 23.3 & 7.4 & 23.7 & 4.6 \\
\hline 1951 & 126.9 & 63.8 & $\varepsilon .:$ & 23.5 & 7.4 & 24.1 & 4.3 \\
\hline 1952 & 128.1 & 61.6 & 8." & 24.2 & 7.5 & 26.1 & 4.2 \\
\hline 1953 & 134.7 & 63.0 & 9.7 & 25.1 & 7.5 & 29.3 & 4.5 \\
\hline 1954 & 137.0 & 61.5 & 11.0 & 25.5 & 7.7 & 31.3 & 4.4 \\
\hline 1955 & 134.1 & 56.1 & 11.3 & 25.4 & 7.8 & 33.4 & 4.0 \\
\hline 1956 & 133.8 & 52.0 & 11.6 & 26.6 & 7.9 & 35.6 & 4.0 \\
\hline 1957 & 136.2 & 50.1 & 12.3 & 28.1 & 8.2 & 37.5 & 4.2 \\
\hline 1958 & 137.4 & 49.6 & 12.9 & 28.5 & 8.3 & 38.2 & 4.5 \\
\hline 1959 & 141.3 & 48.3 & 13.5 & 29.0 & 8.7 & 40.7 & 4.3 \\
\hline 1960 & 144.0 & 46.8 & 14.3 & 30.5 & 9.1 & 43.3 & 4.6 \\
\hline 1961 & 142.4 & 45.0 & 14.3 & 30.4 & 9.2 & 43.5 & 4.7 \\
\hline 1962 & 143.7 & 43.8 & 14.5 & 30.9 & 9.6 & 45.0 & 4.9 \\
\hline 1963 & 144.0 & 41.7 & 14.6 & 31.0 & 10.2 & 46.5 & 5.1 \\
\hline 1964 & 145.9 & 40.4 & 14.8 & 31.4 & 10.9 & 48.5 & 5.5 \\
\hline 1965 & 141.8 & 36.8 & 14.4 & 31.3 & 11.1 & 48.2 & 5.3 \\
\hline 1966 & 139.7 & 34.5 & 14.2 & 32.1 & 11.4 & 47.6 & 5.1 \\
\hline 1967 & 141.1 & 34.1 & 14.3 & 33.6 & 11.7 & 47.5 & 5.3 \\
\hline 1968 & 139.9 & 32.7 & 14.2 & 34.2 & 11.6 & 47.1 & 5.1 \\
\hline 1969 & 141.5 & 30.3 & 14.5 & 35.8 & 12.0 & 47.8 & 5.1 \\
\hline 1970 & 143.6 & 30.2 & 15.0 & 37.8 & 12.4 & 48.3 & 5.2 \\
\hline 1971 & 143.8 & 29.8 & 15.3 & 37.5 & 12.8 & 48.3 & 5.1 \\
\hline 1972 & 141.9 & 27.9 & 14.9 & 37.4 & 13.1 & 48.5 & 5.0 \\
\hline 1973 & 141.7 & 25.8 & 14.3 & 38.5 & 13.5 & 49.6 & 5.0 \\
\hline 1974 & 144.0 & 24.8 & 14.4 & 41.3 & 13.7 & 49.8 & 5.6 \\
\hline 1975 & 142.7 & 27.9 & 14.0 & 39.4 & 13.1 & 48.3 & 6.0 \\
\hline 1976 & 143.6 & 29.4 & 13.6 & 38.7 & 12.8 & 49.2 & 6.5 \\
\hline 1977 & 144.3 & 29.0 & 13.1 & $38.4^{\circ}$ & 12.8 & 51.0 & 6.5 \\
\hline 1978 & 143.3 & 28.0 & 12.6 & 37.8 & 12.7 & 52.1 & 7.4 \\
\hline
\end{tabular}

Notes: Data are yearend credit market debt totals as percentages of fourthquarter gross national product, seasonally adjusted, at annual rate.

Detail may not add to totals because of rounding.

Source: Board of Governors of the Federal Reserve System. 
associated with the fall of prices at the end of world War $I$, the nonfinancial economy's reliance on debt, scaled in relation to economic activity, has show essentially no trend over the past sixty years. At $143 \%$ as of yearend 1978, the debt ratio was virtually unchanged fron $142 \%$ in 1921 . Nonfinancial borrowers' outstanding debt rose significantly in relation to gross national product only during the depression years 1930-33, when gross national product itself not only was well below trend but also was falling too rapidly for the pay-down of debt to keep pace. ${ }^{9}$ otherwise the econony's total nonfinancial debt ratio has remained roughly steady throughout this period. Indeed, as Table 3 documents in greater detail, the debt ratio has been especially steady during the most recent quarter-century, exhibiting only a slight upwara trend and a small amount of cyclicality due to fluctuations of gross national product around its growth trend. ${ }^{10}$ From this overall perspective, therefore, the years since world war II have largely represented a continuation of the pre-war era:

It is interesting to speculate about the underlying economic behavior that has held the economy's total outstanding nonfinancial debt so steady in relation to its nonfinancial activity. Several different kinds of behavinr, not mutually exclusive, may have contributed to this phenomenon. First, the risk of default typically prevents either individuals or businesses from borrowing much in excess of their ownership of (explicit or implicit) collateral, and physical assets constitute the only such collateral that most nonfinancial borrowers can provide. To the extent that private wealth holders in the economy seek to maintain their net worth in relation to their incomes by accumulating more physical assets as they own fewer government-issued financial assets, therefore, their ability to issue their own debt will rise 
as the predominance of government-issued debt declines. Alternatively, some private borrowers may be able to issue as much debt as they want in relation to their incomes, but may also recognize that their liability for future tax payments to support the government's debt: service obligations makes the government's debt in sorne ways equivalent to their own. As their indirect obligations to help service government-issued debt decline, therefore, they become willing to incur an increasing amount of direct obligations for their own debt. Finally, since financial intermediaries must issue their own liabilities approximately in proportion to whatever assets they hold, the amount of debt liabilities that the nonfinancial economy in total issues and the amount of financial assets that the nonfinancial economy in total holds must be about equal. If private wealth holders in the economy have steady demands for financial assets in relation to their incomes, then the decline of government-issued debt will clear tine way for the market as a whole to absorb more private debt, so that this apparent stability on the borrowing side of the financial markets in reality simply mirrors a more fundamental stability on the lending side. Regardless of the relative importance of these (and possibly other) kinds of economic behavior in explaining the stability of the economy's nonfinancial debt ratio, however, that stability has now remained one of the major regularities of the economy's performance over a long period of time. ${ }^{11}$

In sharp contrast to the steadiness of the American nonfinancial economy's overall reliance on debt, the debt issuing behavior on the part of specific categories of nonfinancial borrowers has shown widely divergent patterns. Here the ongoing post-war trend toward ever less federal government debt and ever more private debt in relation to gross national. 
product marks a sharp break from the years immediately before. During the 1920s the government was gradually repaying the debt burden it had assumed during World War $I^{12}$ and in these years the private sector was increasing its relative indebtedness. During the 1930s, however, the ratio of the government's debt to gross national product increased by a factor of twoand-a-half (from $18 \%$ in 1930 to 458 in 1940), and during worid war II it increased by yet another two-and-a-half (to 1198 in 1945). The financial system absorbed this rapid relative growth of government indebtedness at first by a temporary increase in the total nonfirancial debt ratio, and then by a sharp reduction in outstanding private debt in relation to economic activity. Since World War II, however, the federal government has again been "repaying" its debt - not by actual repayment from budget surpluses but by the growth (in recent years, mostly the inflation) of economic activity - so that in 1978 the ratio of its debt to gross national product was again down to $28 \%$, almost identical to the value in 1918. From the perspective of its total absorption of resources from the financial markets, therefore, the government's posture during the bulk of the post World War II period has mostly resembled that of the 1920 s and has stood in contrast to that of the 1930 s and the war itself.

The post-war rise of the private debt economy, following as it did the decline in reliance on private debt during the 1930s and the war years, has mirrored the change in the federal government's behavior. Both businesses and individuals have participated in this post-war resurgence of private debt. The outstanding debt of businesses, which declined in relation to gross national product from 1238 in 1932 to 298 in 1946, has risen in the post-war years to $50 \%$ in 1978 (in comparison with 
$84 \%$ in 1921). The debt ratio for householis, which first rose from $15 \%$ in 1921 to $34 \varepsilon$ in 1932 and then declined to $11 \%$ in 1944 , has risen to $52 \%$ in 1978. On a short-run basis the data, especially for businesses, exhibit modest cyclical varjation in a direction which partly offsets the cycidcality of the government's indebtedness. Nevertheless, over the post-war period as a whole, the trend toward increasing reliance on debt by the private sector has been clear.

In sum, the sustained large-scale turn toward private debt has been one of the principal ways in which the American financial markets in the post-war period have changed, at least in comparison tc their more immediate pre-war experience. An important question, which this essay leaves unresolved, is whether this resurgence of private debt has primarily constituted merely a return to "normality" after the aberration of the depression and the war or, instead, a shift to a greater "normal" indebtedness than that which prevailed half a century ago. Both factors have no doubt contributed at least to some extent. That the years 1930-45 constituted an aberration, and that a large part of the post-war trend has represented a reversal of that aberration, is certainly plausible enough. Moreover, as the discussion below brings out, after the war the relative indebtedness of some categories of nonfinancial borrowers rose steaaily for one or two decades but then reached a plateau for some time, perhaps indicating completion of the reversal process and re-attainment of the relevant pre-war (and pre-depression) norms. Nevertheless, the plateauing of businesses' relative indebtedness in the past few years may have been a reflection of cyclical factors rather than longer-run forces, and, after a hiatus of over a decade, households have begun to increase their relative 
indebtedness once again. Even apart from the evidence of experience itself, there are a pxiori reasons for believing that the progressive development of intermediation in the American financial markets, discussed in Section III below, may have created an environment that is indeed consistent with a higher "normal" private debt ratio than that which characterized the pre-war economy.

\section{B. Specific Nonfinancial Borrowers' Debt Issuing Behavior}

Before going on to examine changes in patterns of intermediation and in asset holding behavior, it is useful to gain a better understanding of the way in which private debt has come to play tinis greater role in the financing of economic activity by focusing briefly on the post-war borrowing experience of the principal specific groups whose needs the American financial markets serve.

Businesses. Table 4 provides an indication of the changing absolute and relative magnitudes of American nonfinancial corpcrate businesses' financial needs by presenting data, in dollars and as a ratio to gross national product, showing the average volume of corporations' uses of funds during successive five-year segments of the post-war period to date (ara the three-year average for 1976-78). On the whole, the experience of unincorporated businesses has been roughly similar to that of corporations in this regard. Corporate businesses' total uses of funds have grown not only absolutely but also in comparison to the overall scale of the nation's economic activity, although this increase has entirely come in the 1960s and 1970s. Corporation's uses of funds for all purposes first declined from an average 9.98 of gross national product during $1946-50$ to 9.28 during 
Table 4

Uses of Funds by U.S. Nonfinancial Corporate Businesses

\begin{tabular}{|c|c|c|c|c|c|c|}
\hline & \multirow{3}{*}{$\begin{array}{r}\text { Total } \\
\text { Uses }\end{array}$} & \multicolumn{2}{|c|}{ Capital Expenditures } & \multicolumn{2}{|c|}{$\begin{array}{l}\text { Net Acquisition of } \\
\text { Financial Assets }\end{array}$} & \multirow{2}{*}{$\begin{array}{l}\text { Memorandum: } \\
\text { GDP of } \\
\text { Non-financial } \\
\text { Corporate } \\
\text { Business } \\
\end{array}$} \\
\hline & & Total & Plant \& Equip & Total & Liquid Assets & \\
\hline \multicolumn{6}{|c|}{ Billions of Dollars } & \\
\hline $1946-1950$ & 25.0 & 18.7 & 15.5 & 6.4 & 1.0 & 128.4 \\
\hline $1951-1955$ & 34.2 & 27.1 & 23.3 & 7.1 & 1.9 & 192.2 \\
\hline $1956-1960$ & 42.3 & 35.1 & 31.8 & 7.2 & -0.4 & 250.6 \\
\hline $1961-1965$ & 62.1 & 47.7 & 40.2 & 14.4 & 2.3 & 335.2 \\
\hline $1966-1970$ & 98.5 & 78.1 & 66.6 & 20.4 & 1.3 & 496.8 \\
\hline $1971-1975$ & 152.6 & 108.8 & 97.3 & 43.8 & 11.5 & 741.7 \\
\hline \multirow[t]{2}{*}{$1.976-1978$} & 224.8 & .268 .3 & 144.8 & 56.5 & 8.7 & 1113.7 \\
\hline & \multicolumn{5}{|c|}{ Percent of GNP } & \\
\hline $1946-1950$ & 9.9 & 7.5 & 6.2 & 2.4 & 0.3 & 51.4 \\
\hline $1951-1955$ & 9.4 & 7.5 & 6.4 & 1.9 & 0.5 & 53.1 \\
\hline $1956-1960$ & 9.2 & 7.6 & 6.9 & 1.5 & -0.1 & 54.3 \\
\hline $1961-1965$ & 10.3 & 7.9 & 6.6 & 2.4 & 0.4 & 55.7 \\
\hline $1966-1970$ & 11.4 & 9.1 & 7.7 & 2.3 & 0.1 & 57.3 \\
\hline $1971-1975$ & 11.9 & 8.4 & 7.5 & 3.4 & 0.9 & 57.2 \\
\hline $1976-1978$ & 11.7 & 8.8 & 7.6 & 2.9 & 0.5 & 58.6 \\
\hline
\end{tabular}

Notes: Data are averages of annual flows, in dollars and as percentages of annuall gross national product. Detail may not add to totals because of rounding.

Source: Board of Governors of the Federal Reserve System. 
1956-60 and then rose by more than one-fourth, reaching 11.98 during 1971-75. As the memoranain item in the table shows, the nonfinancial activity of the corporate sector, as measured by its gross domestic product, has risen almost throughout the post-war period, so that at least a part of this greater relative use of funds in recent years may have refiected greater relative nonfinancial activity. Within the overail total, uses of furds for purposes of physical investment - including plant, equipment, reai estate, inventories, and other real investments - has consistently dominated uses of funds for purposes of acquiring financial assets, and has also accounted for most of the increase in total uses in relation to gross national product. Nonfinancial corporations have also consistently used some funds to acquire (mostly nonliquid) financial assets, thereby acting in part as financial intermediaries.

Against this background of corporate businesses' needs for funds in their ongoing ordinary nonfinancial activity; Table 5 presents five-year average data, in dollars and as percentages of total sources of funds, showing how corporations have financed these needs. ${ }^{13}$ After world war II the balance of corporate financing first shifted toward internally generated funds including both depreciation allowances and undistributed profits. Beginning in the early 1960s, however, it shifted back toward external funds, including both debt and equity issues. Internal funas provided an average $67 \%$ of corporations total funds requirements during 1951-55 and 69\% during 1956-60, but then fell to only $55 \%$ during 1971-75. Also over these years depreciation allowances increased in importance, and retained earnings (in other words, internal additions of common equity) decreased in importance, among the sources of internal funds themselves. To the extent that 
Table 5

Sources of Funds to U.S. Nonfinancial Corporate Businesses

\begin{tabular}{|c|c|c|c|c|c|c|}
\hline \multirow[b]{2}{*}{$\begin{array}{l}\text { Total } \\
\text { Sources } \\
\end{array}$} & \multicolumn{3}{|c|}{ Gross Internal Funds } & \multicolumn{3}{|c|}{ Net Increase in Liabilities } \\
\hline & Total & $\mathrm{CCA}$ & $\begin{array}{l}\text { Undis- } \\
\text { tributed } \\
\text { Profit } \\
\end{array}$ & Total & $\begin{array}{l}\text { Equity } \\
\text { Issues }\end{array}$ & $\begin{array}{c}\text { Credit } \\
\text { Market } \\
\text { Debt } \\
\end{array}$ \\
\hline \multicolumn{7}{|c|}{ Billions of Dollars } \\
\hline 30.3 & 18.6 & 6.7 & 11.4 & 11.8 & 1.1 & 5.5 \\
\hline 35.3 & 23.5 & 13.2 & 9.5 & 11.8 & 1.9 & 6.6 \\
\hline 47.0 & 32.6 & 21.6 & 10.0 & 14.4 & 2.0 & 10.0 \\
\hline 69.1 & 46.0 & 31.3 & 13.1 & 23.1 & 0.7 & 14.0 \\
\hline 111.2 & 64.5 & 46.7 & 16.1 & 44.7 & $2: 5$ & 30.7 \\
\hline 182.7 & 99.7 & 70.9 & 25.8 & 83.0 & 8.8 & 50.4 \\
\hline 267.6 & 156.3 & 102.5 & 49.0 & 1.11 .2 & 5.3 & 73.2 \\
\hline
\end{tabular}

Percent of Total Sources of Funds

$\begin{array}{llllllll}1946-1950 & 100.0 & 61.2 & 22.2 & 37.4 & 38.8 & 3.7 & 18.0 \\ 1951-1955 & 100.0 & 66.5 & 37.2 & 26.8 & 33.5 & 5.4 & 48.5 \\ 1956-1960 & 100.0 & 69.4 & 46.0 & 21.1 & 30.6 & 4.3 & 21.1 \\ 1961-1965 & 100.0 & 66.6 & 45.3 & 19.0 & 33.4 & 0.9 & 20.2 \\ 1966-1970 & 100.0 & 59.0 & 42.8 & 14.8 & 41.0 & 2.3 & 28.1 \\ 1971-1975 & 100.0 & 54.6 & 38.8 & 14.1 & 45.4 & 4.8 & 27.6 \\ 1976-1978 & 100.0 & 58.4 & 38.3 & 18.3 & 41.6 & 2.0 & 27.3\end{array}$

Notes: Data are averages of annual fiows, in dollars and as percentages of total sources. Detail may not add to totals because of rounding.

Source: Board of Governors of the Federal. Reserve System. 
depreciation allowances represent genuine consumption of the capital stock ratiner than merely a way of redefining profits so as to render them exempt from corporate income taxes, therefore, the decline in the contribution of internally generated funds to the growth of the corporate sector has been even more pronounced than these data suggest. ${ }^{14}$ During 1974-77 the effects of the severe business recession and recovery temporarily reversed the trend toward external finance, so much so that corporations' outstanding indebtedness fell from $41 \%$ of gross national product to $38 \%$. Since then, however, corporations have apparently resumed the financing patterns that had predominated for a decade and a half before the unusually deep recession.

A further feature of corporate financial behavior that emerges clearly from Table 5 is the increase in importance of debt, and corresponding decline in importance of equity (until the early 1970s), among corporations' external sources of funds. New issues of equity (net of retirements) accounted for an average of nearly $15 \%$ of corporations' external funds sources during the 1.950 s but then less than 5\% during the 1960s, and in three years out of ten during the 1960 s equity retirements actually exceeded new issues. Moreover, the data shown in Table 5 importantly understate both the magnitude and the persistence of the shift to debt finance. What little equity issuance took place during the 1960 s typically represented initial public offerings of speculative new ventures aimed at a segment of the investing public that was willing to bear substantial risk. Established corporations largely avoided the equity market. In addition, the bulge of equity offerings during the early 1970 s primarily represented only one sector of American industry (public utility companies), and it consisted in large part of preferred shares which are in many respects simply bonds that 
receive special tax treatment for corporate investors. 15

Businesses i increasing reliance on debt financing has probably reflected several influences on corporate financial decision making. To begin, most American businesses emerged from world war II carrying debt that was, in relation to their volume of production and profits, very small in comparison with their pre-war experience. As Figure 1 shows, nonfinancial business indebtedness in relation to gross national product peaked in 1932 and then fell slowly during the remainder of the 1930s. The most rapid decline, however, came during the war years, as the overall business debt ratio fell from $63 \%$ in 1940 to $27 \%$ in 1945 (40\% to $17 \%$ for corporations). It is at least possible, therefore, that the entire subsequent increase to $55 \%$ at the 1974 peak ( $37 \%$ for corporations) sinply represented a slow restoration - which may not yet be complete - of a perceived normal indebtedness that has remained unchanged since before the war. Indeed, by comparison with the standard of the 1920s, the post-war rise in corporate indebtedness has been modest thus far.

Other, more specific explanations are also available, however. First, any private borrower's willingness to incur aebt liabilities presumabiy reflects confidence in the ability to meet these obligations under a wide range of plausible circumstances, including both those particular to the borrower and those general to the economy. As business decision makers became aware of the American economy's distinctly greater stability and prosperity in the post-war era, they probably associated a smaller risk with any given level of indebtedness in relation to either balance sheet or income reference points. Second, the secular acceleration of inflation and rise of nominal interest rates has provided a further incentive for taxable 
borrowers to increase their indebtedness. As Figure 2 shows, on average nominal interest rates have about kept pace with inflation, so that "real" interest rates have remained roughly unchanged during the post-war period. Given the deductability of interest payments against income for tax purposes, however, after-tax "real" interest rates faced by corporate borrowers have been negative almost throughout this period, and have become progressively more negative since the early 1960 s - exactly the period of greatest increase in the debt share of total sources of funds. ${ }^{16}$ Finally, at least throughout the 1960s, corporate financial decision makers appear to have operated almost continually under the opinion that equities were somehow "undervalued.". Especially during the 1960 s the belief that equities were undervalued on a widespread basis led not only to the paucity of new equity issues by major corporations but also to such developments as a wave of conglomerate mergers largely financed by debt. In fact, as Figure 3 shows, equity prices on average had risen sharply during the 1950 s and 1960s, both nominally and on a price-adjusted basis. Since then there has been little trend movement nominally and a large decline in real terms, so that any reluctance to issue new equities in the late 1960 s because of undervaluation appears (with the benefit of hindsight) to have been misplaced.

Whatever its cause, the shift by corporations from internal funds generation to external financing and from equity to debt within that external financing total, together with similar trends among nonincorporated businesses, has been a major feature of the post-war American financial markets. Table 6 presents data showing the total accumulation and also the maturity composition of corporate businesses' outstanding debt. ${ }^{17}$ These 


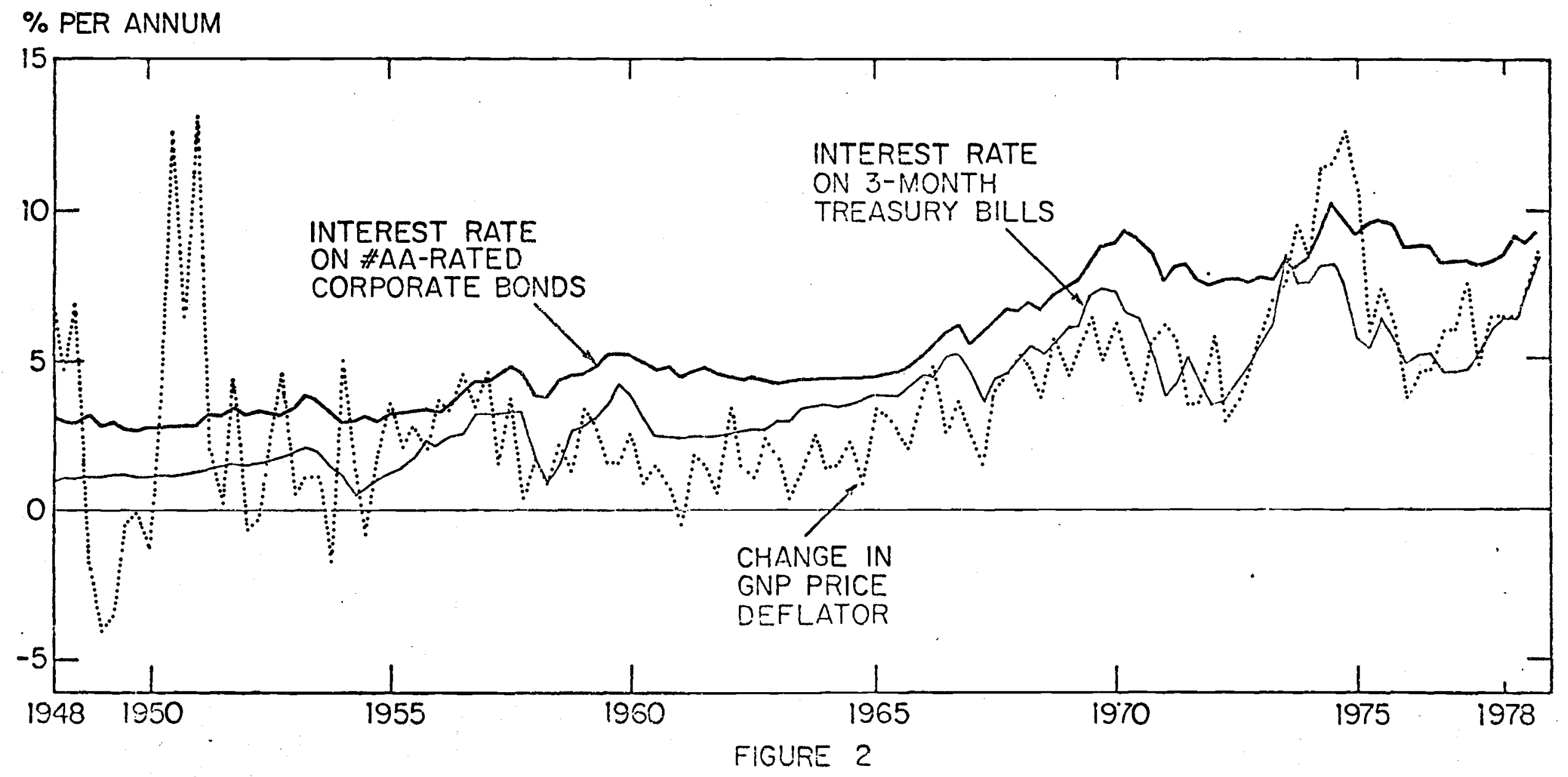

INTEREST RATES AND PRICE INFLATION 


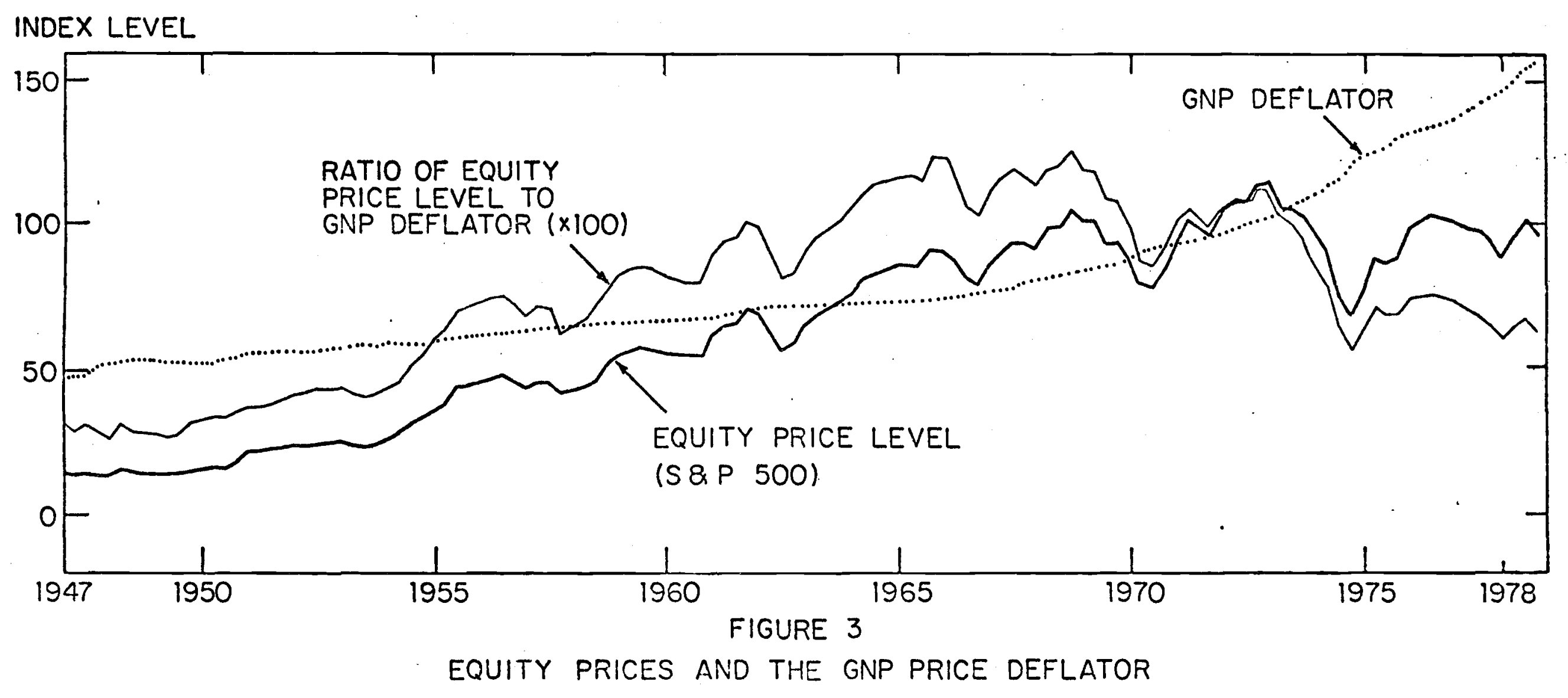




\section{Table 6}

Outstanding Debt of U.S. Nonfinancial Corporate Businesses

\begin{tabular}{lccc} 
& $\begin{array}{c}\text { Total } \\
\text { Credit Market } \\
\text { Debt }\end{array}$ & Long-Term & Short-Term \\
\cline { 2 - 3 } & 60.9 & 48.6 & 12.4 \\
$1946-1950$ & 91.5 & 72.7 & 18.7 \\
$1951-1955$ & 133.9 & 106.8 & 27.1 \\
$1956-1960$ & 191.3 & 151.9 & 39.5 \\
$1961-1965$ & 309.3 & 238.3 & 71.0 \\
$1966-1970$ & 523.4 & 396.7 & 126.8 \\
$1971-1975$ & 760.3 & 568.8 & 191.5 \\
$1976-1978$ & & &
\end{tabular}

Percent of Total Debt

$\begin{array}{llll}1946-1950 & 100.0 & 79.7 & 20.3 \\ 1951-1955 & 100.0 & 79.5 & 20.5 \\ 1956-1960 & 100.0 & 79.8 & 20.2 \\ 1961-1965 & 100.0 & \cdots 79.4 & 20.6 \\ 1966-1970 & 100.0 & 77.0 & 23.0 \\ 1971-1975 & 100.0 & 75.8 & 24.2 \\ 1976-1978 & 100.0 & 74.8 & 25.2\end{array}$

Notes: Data are averages of yearend credit market debt outstanding, in dollars and as percentages of the annual total. Detail may not add to totals because of rounding. Source: Board of Governors of the Federal Reserve System. 
data show clearly that the large shift to debt financing beginning in the mid 1960s also brought a slow increase in the short-term share of the debt, thereby breaking away from the virtually fixed maturity composition that had prevailed since the end of world War II. ${ }^{18}$

Individuals. The substantial post-war increase in 'nouseholds' relative indebtedness, shown in Figure 1 and Table 3, has probably reflected behavioral influences analogous to those identified above as likely causes of the rise in businesses' reliance on debt. Initially just the return to borrowing standards that had prevailed before the war, then a changing perception of tolerable debt levels as confidence in the economy's stability and prosperity became widespread, and finally the growing after-tax incentive for those in higher tax brackets to borrow as price inflation and nominal interest rates rose together, ${ }^{19}$ all contributed to individuals' greater willingness to borrow.

Unlike businesses, however, individuals during the post-war: period have increased their outstanding debt well beyond the relationship to gross national product that prevailed during the pre-war years. Households' outstanding debt gradually rose from $15 \%$ of gross national product in 1921 to $24 \%$ in 1929 , then temporarily rose somewhat further in the early 1930 s (when gross national product was well below trend), but then stabilized again at an unvarying $25 \%$ throughout 1936-40. When individuals emerged from World war II with a debt ratio of only 138 in 1945 (the low had been 118 a year earlier), they presumably felt ample room to borrow heavily. Individuals pushed their indebtedness relative to gross national product past the 25\% pre-war norm as early as 1952, however, and continued to increase it virtually without interruption until 1964 when it reached $48 \%-$ 
a level at which it remained almost constant through 1975 . Hence it appeared that individuals had reached a new post-war capacity level of tolerable debt. Just during the late 1970s, however, individuals have once again begun to increase their relative indebtedness. All of these changes in households' indebtedness in relation to gross national product have also represented changes in relation to personal disposable income, which has claimed a steady average of $69 \%$ of the gross national product, with no trend at all, throughout the post-war period.

Tables 7, 8 and 9 present data for households comparable to that shown in Tables 4,5 and 6 for nonfinancial corporate businesses. First, Table 7 indicates households' changing financial needs by showing their total uses of funds for all pruposes, aivided between current consumpticin of non-durable goods and services and all "investment" type uses - incluaing new residential construction, outlays for durabie goods, and financial investment. Whether the evolution of individual behavior documented in Table 7 constitutes a case for change or continuity within the post-war period is largely a matter of emphasis. Nondurable consumption has remainea a steady five-ejghths of gross national product, without any trend, since the early 1950s. Households' total non-consumption uses of funds remained roughly steady at one-fifth of the gross national product until 1970, but has risen sharply since then. Within this total, both durables purchases and residential construction have held a steady relation to overall economic activity throughout, but the net acquisition of financial assets has approximately doubled over the post-war years, rising from an average $6 \%$ of gross national product during the late 1940 s and 1950 s to $10-128$ in the 1970 s. While it is important not to lose sight of the distribution of assets and 


\section{Table 7}

Uses of Funds by U.S. Households

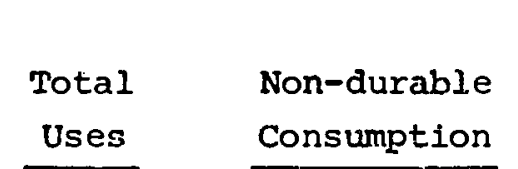

$\frac{\text { Investment Uses of Funds }}{\text { Durable }} \begin{gathered}\text { Residential } \\ \text { Total Net Acquisition of } \\ \text { Expenditure }\end{gathered}$

Memorandum:

Personal

Uses Consumption

sposable

Billions of Dollars

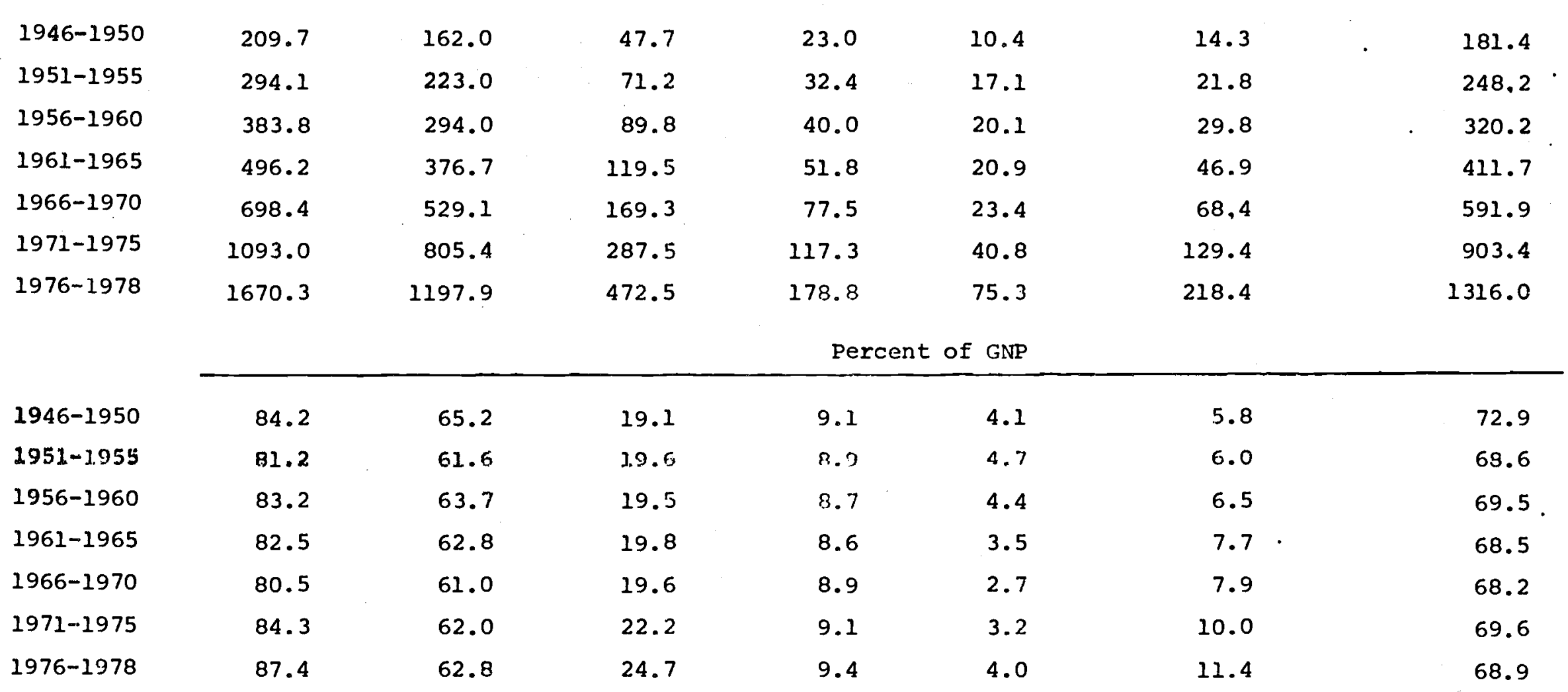

Notes: Data are averages of annua!. flows, in dollars and as percentages of annual gross national product. Dctail may not add to total.s because of rounding.

Source: Board of Governors of the Federal Reserve system. 
Table 8

Sources of Funds to U.S. Households

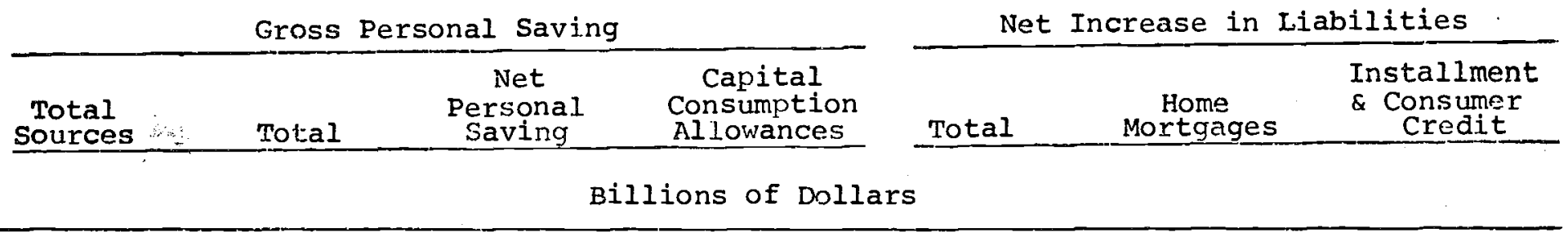

\begin{tabular}{|c|c|c|c|c|c|c|c|}
\hline $1946-1950$ & 45.4 & 36.9 & 21.1 & 15.7 & 8.5 & 4.8 & 3.6 \\
\hline $1951-1955$ & 68.2 & 54.7 & 27.2 & 27.5 & 13.6 & 8.3 & 3.9 \\
\hline $1956-1960$ & 85.9 & 69.3 & 29.2 & 40.1 & 16.6 & 10.8 & 4.0 \\
\hline $1961-1965$ & 114.6 & 88.4 & 39.6 & 48.8 & 26.2 & 15.4 & 7.6 \\
\hline $1966-1970$ & 166.6 & 138.0 & 71.2 & 66.8 & 28.5 & 15.2 & 8.0 \\
\hline $1971-1975$ & 277.3 & 23.7 .5 & 110.9 & 106.6 & 59.8 & 37.7 & 16.0 \\
\hline $1976-1978$ & 442.1 & 303.8 & 141.2 & 162.6 & 138.3 & 86.1 & 38.9 \\
\hline
\end{tabular}

Percent of rotal Sources

\begin{tabular}{|c|c|c|c|c|c|c|c|}
\hline $1946-1950$ & 100.0 & 81.3 & 45.6 & 34.7 & 18.7 & $10: 6$ & 7.9 \\
\hline $1951-1955$ & 100.0 & 80.1 & 39.8 & 40.3 & 19.9 & 12.1 & 5.8 \\
\hline $1956-1960$ & 100.0 & 80.6 & 34.0 & 46.6 & 19.4 & 12.6 & 4.6 \\
\hline $1961-1965$ & 100.0 & 77.2 & 34.6 & 42.6 & 22.8 & 13.5 & 6.7 \\
\hline $1966-1970$ & 100.0 & 82.9 & 42.8 & 40.1 & 17.1 & 9.1 & 4.8 \\
\hline $1971-1975$ & 100.0 & 78.4 & 40.0 & 38.4 & 21.6 & 13.6 & 5.8 \\
\hline $1976-1978$ & 100.0 & 68.7 & 31.9 & 36.8 & 31.3 & 19.5 & 8.8 \\
\hline
\end{tabular}

Notes: Data are averages of annual flows, in dollars and as percentages of total sources. Detail may not add to totals because of rounding.

Source: Board of Govermors of the Federa]. Reserve System. 


\section{Table 9}

- Outstanding Debt of U.S. Households

\begin{tabular}{cccc}
$\begin{array}{c}\text { Total } \\
\begin{array}{c}\text { Credit Market } \\
\text { Debt }\end{array}\end{array}$ & $\begin{array}{c}\text { Home } \\
\text { Mortgacjes } \\
\text { Billions of Dollars }\end{array}$ & $\begin{array}{c}\text { Installment } \\
\text { \& Consumer } \\
\text { Credit }\end{array}$ & Othex \\
\hline 52.7 & 31.2 & 17.9 & 3.6 \\
107.2 & 64.1 & 36.0 & 7.1 \\
183.3 & 114.8 & 56.0 & 12.5 \\
286.6 & 181.1 & 84.0 & 21.5 \\
423.0 & 259.0 & 126.6 & 37.4 \\
657.0 & 400.3 & 195.2 & 61.5 \\
1010.5 & 637.6 & 292.7 & 80.2
\end{tabular}

$1946-1950$

1951-1955

1956-1960

1961-1965

$1966-1970$

1971-1975

1976-1978

$1946-1950$

1951-1955

1956-1960

1961-1965

1966-1970

1971-1975

1976-1978

Percent of Total Debt

Notes: Data are averages of yearend credit market debt outstanding, in dollars and as percentages of the annual total. Detail may not add to totals because of rounding.

Source: Board of Governors of the Federal Reserve System. 
liabilities - the people who borrow are often not the same ones who accumulate assets - on an aggregated basis the notion that individuals have increased their borrowing (relative to economic activity) either to finance investment in houses and durables or to finance current consumption turns out to be false. Instead, they have borrowed more and simultaneousiy held more financial assets.

A comparison of households' total uses of funds versus personal cisposable income, shown as a memorandum item in Table 7 , indicates that individuals have had to be net borrowers throughout the post-war period. After showing little trend for a quarter-century, the shortfall of disposable income from total uses of funds has increased sharply in the 1970s. The data in Table 8 show how households have financed their growing needs for funds. 20 Here again the data suggest a long period of stability, followed by some change in household behavior either at the beginning of the 1970 s or perhaps the 1960s. Until then the balance of saving and borrowing as sources of funds remained largely unchanged. More recently individuals have relied more heavily on borrowing, incluaing both mortgages and consumer credit (primarily installment credit ${ }^{21}$ ). Table 9 indicates the accumulation and also the relatively stable composition of this expanding individual dest by type of borrowing. Subject to some variation primarily associated with the pace of homebuilding activity and the movement of house prices, home mortgages have accounted for a fairly steady five-eighths of total household indebtedness throughout the post-war period. Consumer credit has gradually shrunk in relation to the total, while the relatively small amount of borrowing in all other forms has gradually grown. State and Iocal Governments. State and local government units 
gradually increased their outstanding debt from $7 \%$ of the gross national product at the end of world war II to just over double that in 1971 before allowing it to decline somewhat in the 1970s. Once again, a major portion of this increase in indebtedness constituted a return to pre-war norms after the aberration of the wartime years. During the 1920 s the state and local government debt ratio had slowly risen from $10 \%$ to $13 \%$, and after some fluctuation in the early 1930 s it stood at $13 \%$ in 1941 also. At least until 1960, therefore, the post-war increase was merely a restoration of the previous relative debt level. For the next decace outstanding state and local government debt grew little further in relation to the economy's nonfinancial activity, and in the 1970 s it has again declined to well within its pre-war range.

As Table 10 shows, the leveling of the state and local government debt ratio in the 1960 s and its decline in the 1970 s stand in some contrast to the relative size of state and local governments' non Einancial activity, which continued to grow vigorously through both the 1950 s and the 1960s, and has leveled off but still not declined in the 1970s. State and local government spending has been the single most rapidly growing component of the nation's total spending since World War II. The great surge in the provision of local public services during this period, much of which was associated with the needs created by the post-war baby boom, more than doubled state and local governments' purchases of goocs and services as a share of the gross national product. Only in the 1970s has this growth in spending leveled off, as the demographics have shifted markedly and an increasing number of communities have all but completed their basic social capital installations including schools, hospitals, roads and sewers. 
Table 10

Budget Summary for U.S. State and Local Governments

\begin{tabular}{|c|c|c|c|c|}
\hline \multicolumn{2}{|c|}{ Expenditures } & \multirow{2}{*}{$\begin{array}{c}\text { Net } \\
\text { Acquisition of } \\
\text { Financial Assets }\end{array}$} & \multirow{2}{*}{$\begin{array}{l}\text { Total } \\
\text { Receipts }\end{array}$} & \multirow[b]{2}{*}{$\begin{array}{l}\text { Net Increase } \\
\text { in Liabilities }\end{array}$} \\
\hline Total & $\begin{array}{c}\text { Purchases of } \\
\text { Goods \& Services }\end{array}$ & & & \\
\hline
\end{tabular}

Billions of Dollars

\begin{tabular}{|c|c|c|c|c|c|}
\hline $1946-1950$ & 17.2 & 15.1 & 1.2 & 17.4 & 2.1 \\
\hline $1951-1955$ & 28.0 & 25.7 & 1.6 & 27.4 & 4.4 \\
\hline $1956-1960$ & 43.3 & 40.4 & 1.4 & 42.4 & 5.3 \\
\hline $1961-1965$ & 63.8 & 60.0 & 3.4 & 64.1 & 6.5 \\
\hline $1966-1970$ & 107.1 & 100.7 & 4.3 & 108.1 & 9.7 \\
\hline $1971-1975$ & 185.3 & 172.6 & 10.1 & 194.1 & 16.0 \\
\hline $1976-1978$ & 275.2 & 255.5 & 20.6 & 299.2 & 20.6 \\
\hline
\end{tabular}

Percent of GNP

\begin{tabular}{|c|c|c|c|c|c|}
\hline $1946-1950$ & 6.8 & 6.0 & 0.5 & 6.9 & 0.8 \\
\hline $1951-1955$ & 7.7 & 7.1 & 0.5 & 7.6 & 1.2 \\
\hline $1956-1960$ & 9.4 & 8.7 & 0.3 & 9.2 & 1.1 \\
\hline $1961-1965$ & 10.6 & 10.0 & 0.6 & 10.6 & 1.1 \\
\hline $1966-1970$ & 12.3 & 11.6 & 0.5 & 12.4 & 1.1 \\
\hline $1971-1975$ & 14.2 & 13.3 & 0.8 & 15.0 & 1.3 \\
\hline $1976-1978$ & 14.4 & 13.4 & 1.1 & 15.7 & 1.1 \\
\hline
\end{tabular}

Notes: Data are averages of annual. flows, in dollars and as percentages of annual gross national product. Detail may not add to toials becausc of rounding.

Source: Board of Governors of the Federal Rescrve system. 
The budget data in Table 10 also show that state and local governments on average have typically kept their total receipts, consisting primarily of tax revenues and federal grants, rising in pace with their increasing total expenditures - including primarijy purchases of goods and services, plus small amounts of transfer payments and the excess of interest paid

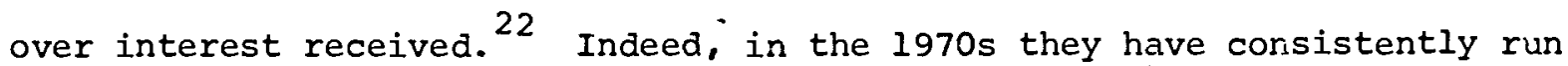
surpluses. $^{23}$ Hence state and local governments' borrowing, which has consisted almost entirely of long-term debt, has served in large part to finance these governments' own investment in finarcial instruments, especially Treasury securities. In 1978, however, the federal government: eliminated the right of state and local governments to earn a positive "spread" by issuing tax exempt (and therefore lower yield) securities in. order to hold (without paying taxes) higher yielding Treasury securities. Hence the relationship between state and local governments' debt issues and their budget surpluses or deficits may well become closer in the future than it has been in the recent past.

Foreign Borrowers. Foreign borrowers have playea a relatively small., though growirg, role in the American financial markets throughout the postwar period. ${ }^{24}$ During the late 3.950 s and early 1960s, discussions of the American balance of payments deficit, which people were just then coming to perceive as a problem, often focused on the strength of the American financial markets and on their ability to extend credit to finance the growth of world trade and development. Even so, as the memorandum column of Table 3 indicates, outstanding debt issued by foreigners in the American markets first equalled $5 \%$ of this country's gross national product only in 1963, and it peaked at an only slightly higher ratio after the imposition of 
capital controls the next year. Moreover, throughout this period and into the 1970s, about half of the foreign borrowing here took the form of loars from the federal government rather than finds advanced by private investors. Foreign debt in American markets did not again reach the 1964 level (in relation to gross national product) until. 1974, after the removal of the capital controls. The subsequent growth has remained nodest through 1978 , although the increasing amount of developing country debt owed to American banks has recently raised widespread questions about these banks' exposure to risks associated with foreign lending.

It is interesting to speculate about whether foreign borrowing would have been a more important activity in Anerican markets but for the restrictive government actions taken in the 1960 s to prevent capital outflows in the interest of maintaining a stronger dollar. From 1964 until 1974 the Interest Equalization Tax effectively prohibited the sale in the United States of debt secuxities issued by foreign borrowers other than Canadian provinces and international institutions like the world Bank, and from 1965 until 1974 the Federal Reserve's so-called Volurtary Foreign Credit Restraint program limited lending abroad by American banks. ${ }^{25}$ These two restrictions along with the Commerce Department's office of Foreign Direct Investment program, which from 1965 to 1974 required Americàn companies to finance abroad whatever funds they were investing abroad, and the advent of effective interest ceilings on domestic deposits (discussed in section IV below) - probably provided the chief impetus to the rapid development of the Eurodollar and Eurobond markets. Without these capital controls foreign borrowers almost certainly would have done more financing in American markets, and might have done much more. Since the removal of capital controls the volume of both American banks' lending abroad and foreign issues in the American bond market has picked up 
sharply, but the Euro markets, now that they are well estailished, remain the major immediate source of dollar credits to most foreign borrowers. ${ }^{26}$ In retrospect it is clear that the capital flow restrictions imposed in the 1960 s had the effect of enhancing the competitive position of, for example, the London financial markets over those in New York.

Federal Government. The federal government's reliance on the American financial markets during the post-war period has largely constituted a return to the experience of the 1920 s after the aberration of the depression and the war years. After World war II the government's outstanding debt fell steadily in relation to gross national product until the mid 1970 s from $119 \%$ in 1945 to $56 \%$ in $1955,37 \%$ in 1965 , and a low of $25 \%$ in 1974 . Although the federal government's budget has rarely been in surplus, only during the years 1949, 1953 and 1975-76 did the impact of business recessions on tax revenues and transfer payments enlarge the deficit to such an extent that the government did not "pay down" the public debt in relation to (temporarily shrunken) nonfinancial activity. Nevertheless, the other post-war recessions - in 1957-58, 1960-61 and 1969-70 - did produce some slowing, though not a reversal, of the overall post-war decline in the goverment's debt ratio. The combined effect of the relatively mild 1969-70 recession and the especially severe $1973-75$ recession has been on balance to halt much of the decline of the public debt ratio in the 1970s, although the government budget projections for 1979-81 that are available as of the time of writing suggest that this decline may now be in progress once again.

Table 11 presents budget summary data relating the federal government's financial needs to its nonfinancial activity. Apart from a one-time jump at the beginning of the 1950 s and subsequent fluctuations associated with 
Table 11

Budget Summary for U.S. Federal Government

\begin{tabular}{lcl} 
& Expenditures \\
\hline Total & Purchases of & Transfer \\
\hline
\end{tabular}

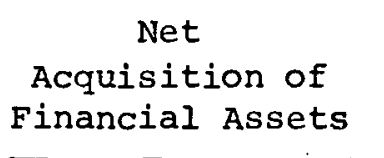

Total

Receipts
Net Increase in Liabiiities

Billions of Dollars

\begin{tabular}{|c|c|c|c|c|c|c|}
\hline $1946-1950$ & 36.5 & 17.2 & 15.1 & -0.8 & 42.9 & -6.3 \\
\hline $1951-1955$ & 68.8 & 48.1 & 16.1 & 1.6 & 67.6 & 3.3 \\
\hline $1956-1960$ & 85.0 & 51.5 & 27.7 & 0.8 & 85.0 & 2.2 \\
\hline $1961-1965$ & 113.7 & 63.6 & 42.7 & 3.4 & 111.6 & 6.5 \\
\hline $1966-1970$ & 176.1 & 92.2 & 72.4 & 3.7 & 171.2 & 10.1 \\
\hline $1971-1975$ & 277.3 & 106.9 & 152.2 & 6.4 & 251.9 & 32.6 \\
\hline $1976-1978$ & 422.2 & 142.2 & 249.8 & 20.6 & 379.6 & 69.4 \\
\hline
\end{tabular}

Percent of GNP

1946-1950

1951-1955

1956-1960

1961-1965

1966-1970

1971-1975

1976-1978

$\begin{array}{rrr}14.7 & 7.0 & 6.1 \\ 19.0 & 13.3 & 4.4 \\ 18.4 & 11.2 & 6.0 \\ 19.0 & 10.6 & 7.1 \\ 20.3 & 10.7 & 8.3 \\ 21.3 & 8.3 & 11.6 \\ 22.1 & 7.5 & 13.1\end{array}$

-0.7
0.5
0.2
0.6
0.4
0.5
1.1

17.3

$-3.0$

18.7

1.0

18.4

0.5

18.6

1.1

19.7

1.2

19.4

2.4

19.8

3.7

Notes: Data are averages of annual flows, in dollars and as percentages of annual gross national product. Detail may not add to totals because of rounding.

Source: Board of Governors of the Federal Reserve System. 
recessions, federal expenditures have grown slowly but steadily in relation to gross national product throughout the post-war period. Within the overall total, however, the mix between transfer payments and direct purchases of goods and services has radically changed. Except for a brief bulge during the Vietnam War years, the share of gross national product claimed by federal goods and services purchases has fallen ever since the early 1950s. By contrast, during this same period federal transfers including grants to state ana lccal governments, Social security benefits and all other income support payments - have risen even more rapidly in relation to gross national product. As a result, total expenditures (which also include the excess of interest paid over interest received) have grown modestly in relative size, and their composition is now nearly two-thirds transfers and only one-third direct purchases instead of the reverse twerity years ago. 27

The federal government typically enlarges its portfolio of directly held financial assets only slowly, so that its borrowing primarily reflects the difference between its total expenditures and its total receipts from tax revenues and Social Security contributions. After a large surplus during the late 1940s and a small deficj.t during the Korean war years, the federal government's budget was in balance on average during the late 1950s. Since then the budget deficit has averaged 0.58 of the gross national product during the 1960s, nearly 28 during the early 1970 s and more than 28 during 1976-78. Even after allowance for the enlargement of the deficit due to the severe 1973-75 recession, the federal budget deficit has shown a slow but steady tendency to grow in relation to the economy's nonfinancial activity. 28 The result has been the continual slowing - and in 1975-76 the temporary 
reversal - of the decline in the federal debt ratio that has dominated the post-war period thus far.

The maturity composition of the debt issued by the federal government has also changed substantially during the post-war period, as Table 12 shows. Federal debt management policy has not only stood in contrast to the pattern of wartime financing but has also undergone several sharp breaks within the post-war years. Especially since the Federal Reserve System's abandonment of bond price stabilization at the beginning of the 1950s, post-war debt management has mostly emphasized short-term rather than long-term financing, driving the mean maturity of the outstanding federal debt down from 113 months in 1946 to a low of only 33 months in 1976. In two distinct periods, however, debt management has gone the other way. During the early 1960 s the government lengthened its outstanding debt, from a mean maturity of 50 months in September, 1960, to 65 months in January, $1965 .^{29}$ In addition, beginning in 1976 and continuing through the time of writing, the gorernment has been lengthening its debt once again. The increase in mean maturity from 33 months in January, 1976, to 43 months as of September, 1979, represents about as rapid a rate of increase as the rate of decrease that predominated on average during the previous thirty years. 
Table 12

Maturity of Privately Held U.S. Treasury Securities

Year

1945

1950

1955

1960

1965

1970

1975

1976

1977

1978

1979
Mean Maturity

116

100

71

58

63

41

29

33

35

40

43

Notes: Data are mean values for December (September for 1979) Source: U.S. Department of the Treasury 
III. Changes in the Working of the Financial Markets

How have the American financial markets in the post-war period met the changing needs that the economy has placed on them? In any well developed financial system it is useful to aistinguish the liability issuing and asset holding activity which takes place directly between nonfinancial participants in the economy, whose respective principal business interests lie elsewhere, from that which takes place through an intermediary whose principal business is financial transactions themselves. In general, changes in how financial markets work to meet the requirements of the nonfinancial economy may represent some combination of changes in the economy's overall degree of intermediation and changes in how the intermediaries go about their business. In fact both aspects together have accounted for changes in the American financial system during the post-war era.

\section{A. The Advance of Financial Intermediation}

Throughout their history, but more so during the twentieth century and especially in the years since World war II, the American financial markets have undergone a shift away from direct transactions beiween nonfinancial borrowers and lenders toward the intervention of financial intermediaries. 30 The development of the commercial banking system and of the life insurance industry in earlier years, and more recently the great expansion of nonbank deposit institutions and both private and public sector pension funds, have been important features of the development of the American financial system. In the post-war period the continuation and even acceleration of the trend toward intermediated financial markets has hardly been independent of the simultaneous rise in the economy's reliance on privately issued debt. 
Instead, the two developments have been natural counterparts. ${ }^{31}$ In comparison with default-free government obligations, risky private securities impose both information and transactions costs that encourage the economy's development of financial intermediaries. Holders for potential holders) of private securities must first discover the specific risks that individual claims against private issuers entail, and then monitor these risks on an ongoing basis. These information costs are especially large in the case of negotiated loans like home mortgages, consumer credit, and bank loans to businesses. Not only economies of scale but also the advantages of specialization favor delegating this information gathering and processing function to third parties. An equally important function performed by financial intermediaries holding private securities is the pooling of specific risks. In transforming the direct claims that they hold into the indirect claims that they issue, intermediaries economize on transactions costs so as to facilitate diversification by enabling investors to own interests (indirectly) in a large number of imperfectly divisible assets. In addition, by pooling many individuals' and businesses' needs for liquidity, deposit intermediaries often change the risk characteristics of the aggregate of assets to be held by issuing claims (often explicit or implicit demand claims) that have a shorter maturity than the claims that they in turn hold. Similarly, pension and insurance intermediaries change the aggregate risk structure that insured parties face by pooling actuarial risks.

Individuals are the principal nonfinancial holders of assets that represent direct claims on other nonfinancial participants in the economy. Individuals' continued willingness to hold such assets therefore constitutes 
a retardant to the advance of financial intermediation, while their reluctance to perform this function creates the basic need for intermediation. Figure 4 shows how American households have shifted tre composition of their financial asset portfolios during the fost-war period. ${ }^{32}$ Households' aggregate holdings of deposit-type liabilities of financial intermediaries have grown continually from the early 1950 s to the late 1970s, not only absolutely but in relation to overall nonfinancial economic activity (and personal income). Households' claims on insurance and pension reserves have also grown on balance during the post-war years, although here the growth has been less steady because of the effect of equity price changes on the valuation of these reserves (see again Figure 3). By contrast, households' direct holdings of nonintermediated debt have declined in relative terms almost continually since world war II, and their direct holdings of equity claims on business corporations have varied mostly with equity price fluctuations, exhibiting little overall relative trend. ${ }^{33}$ since the total size of househoids' financial asset portfolios in relation to gross national product has also shown no overall trend - first declining during the immediate post-var years, then rising sharply in the 1950s, remaining steady through the 1960s, and declining in the 1970 s - these patterns of growth and decline in comparison to gross national product also correspond, for the post-war period as a whole, to growth or decline in shares of households' total portfolio.

Households' increasing preference for claims on intermediaries has appeared even more pronounced from the perspective of their accumulation of financial assets. Table 13 shows households' net acquisition of various categories of financial assets, both in dollars and as a share of the total. 


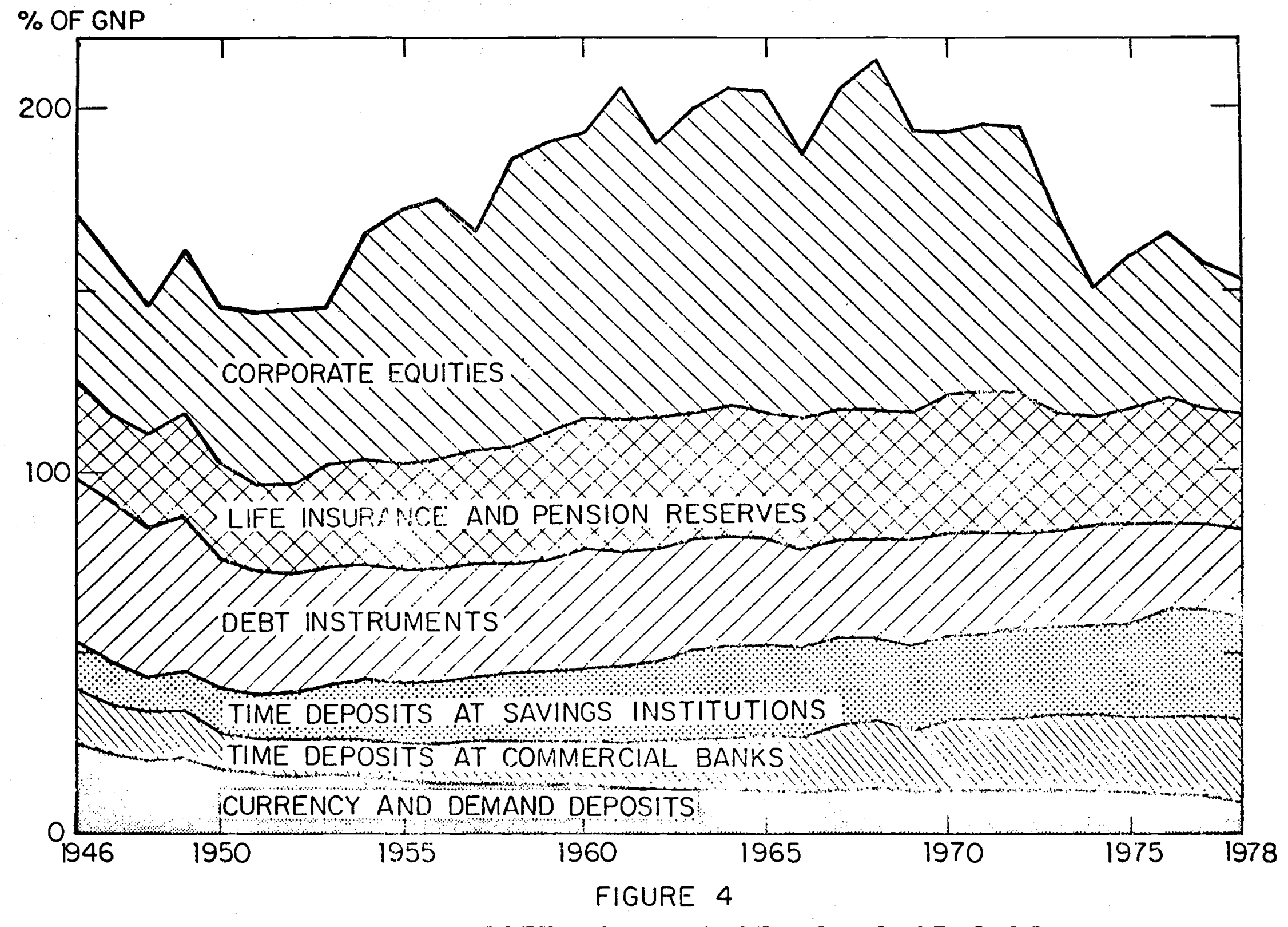

FINANCIAL ASSET HOLDINGS OF U.S. HOUSEHOLDS 
Table 13

Net Acquisjtions of Financial Assets by U.S. Households

\begin{tabular}{|c|c|c|c|c|c|c|c|}
\hline \multirow[b]{2}{*}{$\begin{array}{l}\text { Total } \\
\text { Assets }\end{array}$} & \multirow[b]{2}{*}{ Currency } & \multicolumn{3}{|c|}{ Equities } & \multirow{2}{*}{$\begin{array}{c}\text { Credit } \\
\text { Market } \\
\text { Debt }\end{array}$} & \multirow{2}{*}{$\begin{array}{l}\text { Life Ins. } \\
\text { \& Pension } \\
\text { Reserves }\end{array}$} & \multirow{2}{*}{ Other } \\
\hline & & Total & $\begin{array}{l}\text { Investment } \\
\text { Co. Shares }\end{array}$ & Direct & & & \\
\hline \multicolumn{8}{|c|}{ Billions of Dollars } \\
\hline
\end{tabular}

\begin{tabular}{|c|c|c|c|c|c|c|c|c|}
\hline $1946-1950$ & 14.3 & 3.4 & 1.0 & 0.2 & 0.7 & 1.2 & 5.7 & 3.1 \\
\hline $1951-1955$ & 21.8 & 9.7 & 1.2 & 0.5 & 0.7 & 3.3 & 7.6 & -0.2 \\
\hline $1956-1960$ & 29.8 & 13.0 & 1.0 & 1.4 & -0.4 & 6.5 & 10.6 & -1.3 \\
\hline $1961-1965$ & 46.9 & 27.8 & -1.3 & 2.1 & -3.4 & 5.2 & 14.3 & 0.8 \\
\hline $1966-1970$ & 68.4 & 33.5 & -3.3 & 4.1 & -7.3 & 15.2 & 20.6 & 2.4 \\
\hline $1971-1975$ & 129.4 & 79.3 & -4.6 & -0.2 & -4.4 & $23.2^{\circ}$ & 34.0 & -2.4 \\
\hline $1976-1978$ & 218.4 & 126.5 & -5.2 & -1.0 & -4.2 & 39.1 & 65.3 & -7.3 \\
\hline
\end{tabular}

Percent of Total Net Acquisitions

\begin{tabular}{|c|c|c|c|c|c|c|c|c|}
\hline $1946-1950$ & 100.0 & 23.9 & 6.4 & 1.6 & 4.8 & 8.1 & 39.9 & 21.7 \\
\hline $1951-1955$ & 100.0 & 44.5 & 5.7 & 2.3 & 3.4 & 15.3 & 35.1 & -0.7 \\
\hline $1956-1960$ & 100.0 & 43.7 & 3.5 & 4.7 & -1.2 & 21.8 & 35.5 & -4.5 \\
\hline $1961-1965$ & 100.0 & 59.4 & -2.7 & 4.6 & -7.3 & 11.0 & 30.6 & 1.8 \\
\hline $1966-1970$ & 100.0 & 48.9 & -4.8 & 6.0 & -10.7 & 22.2 & 30.1 & 3.5 \\
\hline $1971-1975$ & 100.0 & 6.1 .3 & -3.6 & -0.2 & -3.4 & 17.9 & 26.2 & -1.9 \\
\hline $1976-1978$ & 100.0 & 57.9 & -2.4 & -0.4 & -1.9 & 17.9 & 29.9 & -3.4 \\
\hline
\end{tabular}

Notes: Data are averages of annual "lows, in dollars and as percentages of annual total net accuisitions. Detail may not add to totals because of rouncing.

Source: Board of Governors of the Federal Reserve system. 
The two features of households' investment behavior that stand out most sharply here are the dominance of deposits throughout the post-war period and the change that took place at the end of the 1950 s in households' net investment in corporate equities. Households purchased more equity shares in corporations than they sold in every year during 1946-57, so that the tripling in value of their direct equity holdings over this period represented the combined result of capital gains and positive net purcinases. By contrast, households have sold more direct equity shares than they have purchased in every year since 1958, so that capital gains have accounted for more than all of the subsequent increase in total value of their direct equity holdings. Moreover, allowing for the shift from direct ownership of equities to indirect ownership via mutual funds does not alter the fundamental picture of individuals' investment behavior. Households in the aggregate were net purchasers of mutual fund shares during the rise of that industry in the 1960s, but not in sufficient quantity to offset the liquidation of their direct equity holdings. More recently, they have been net sellers of both direct equity holdings and mutual fund shares in every year since 1972. The conclusion remains that equity price movements have accounted for more than all of any increase in the value of individuals' equity holdings. Because equity prices have fluctuated widely but shown little net gain in nominal terms since the mid 1960s (see again Figure 3), individuals' aggregaice equity portfolio has therefore shown no trend movement in nominal value and has declined in relative value during the last decade and more. The snift of individuals' investment flows away from equities during the second half of the post-war period probably reflects several considerations in addition to the economies of scale and risk pooling noted above as general 
advantages of intermediation. Changing birth rates, age distributions, and income levels have all played some role. The increasing government provision of heajth, education and income security benefits has also altered the objectives associated with saving for many people. The growing importance of workers' claims on future pension benefits, including job-specific pensions in both the private and public sectors and also Social Security, has in particular changed many people's need to accumulate assets directly to finance their retirement. ${ }^{34}$ Finally, perceptions of the relative returns and risks - including especially inflation risk - associated with different assets have also changed markedly during the post-war period. After the unpegging of bond prices in 1951, fixed-income securities became subject to market risk in addition to inflation risk, and in the 1970 s the inflation risk has increased aramatically. As for equities, during most of the l950s and 1960s, renewed confidence in economic stability and prosperity lessened fears of any collapse of values comparable to that of 1929-33, and in addition many people regarded them as a "hedge" against price inflation. 35 Following the rapid acceleration of inflation and the poor performance of both equity prices and the American economy in the 1970s, however, prevailing opinion has become progressively more skeptical both of the economy's long-run growth prospects and of the usefulness of equities as an inflation hedge. ${ }^{36}$ As the correlations presented in Table 14 show, even during the 1950 s and 1960 s nominal returns on equities never compensated fully for variations in price inflation. ${ }^{37}$ Even so, the table aiso shows that there has been a noticeable shift in the structure of asset returns and risks in the 1970 s. Although individuals are the dominant nonfinancial holders of direct claims on other nonfinancial participants in the economy, businesses also 
Table 14

Asset Returns and Price Inflation

After-Inflation Total Returns

l-month Bills 20-year Bonds Equities $\quad$ Inflation

1953-1978

Mean

Standard Deviation

Correlation with Inflation

1953-72 Subperiod

\section{Mean}

Standard Deviation

Correlation with Inflation

\section{2-78 subperiod}

\section{Mean}

Standard Deviation

Correlation with Inflation
0.41

1.41

$-0.88$

1.02

0.69

$-0.44$
$-1.62$
1.29
$-0.97$

$-0.52$

6.89

$-0.40$

0.18

6.59

$-0.30$

$-2.83$

8.00

$-0.72$
$-4.19$

23.87

$-0.77$
2.36

1.73

1.00
3.69

3.12

1.00

Note: Data in percent per annum. 
advance a substantial amount of direct credit, both to individuals in the form of installment and other consumer credit, and to each other in the form of trade credit and commerciai paper. Even with the ready avaiiability of business credit cards and charge accounts, however, commercial banks and finance companies have increasingly dominated the consumer credit field. The share of outstanding consumer credit owed to nonfinancial businesses (including corporations and others) has fallen from just over one-third in the early 1950s to just under one-sixth in the 1970s. In addition, business lending via purchases of nonfinancial commercial paper has remained relatively small, so that trade credit - typically equal to $15-18 \%$ of the gross national product, and mostly borrowed and lent within the corporate sector - remains the primary vehicle for businesses' holdings of direct claims on nonfinancial obligors.

Foreign investors have held a small but growing share of direct claims on nonfinancial participants in the American economy throughout the post-war period. ${ }^{38}$ The growth of foreign holdings has been especially rapid during the 1970s, as the persistent American balance of payments deficit has transferred assets abroad, especialiy to member countries of the international oil cartel. The rapid recent growth has proceded from a small base, however, so that foreign holdings still represented less than 58 of all direct claims against American nonfinancial obligors as of yearend 1978. Nevertheless, the concentration of foreign (especially foreign official) investments in specific instruments has made foreign holdings of particular importance in some American markets. The yearend 1978 share of federal government securities held abroad, for example, was nearly one-sixth. 
Figure 5 indicates the extent to which the increasing preference for claims on intermediaries by individuals (and, to a lesser extent, other nonfinancial investors) has shifted to intermediaries the task of meeting the needs that nonfinancial participants in the economy have brought to the American financial markets. As of 1978 individuals in the aggregate remained the largest single class of holders of direct claims on nonfinancial borrowers and share issuers - but only by virtue of their continuing domination of the ownership of corporate equities. Because the direct claims that individuals hold consist overwhelmingly of equities (see again Figure 4), the household share of ownership of the total of direct claims outstanding has varied with fluctuations in equity prices. Overall, however, the household share has declined, as has the share held by all other nonfinarcial investors. As the share of direct claims on nonfinancial entities held by all nonfinancial investors has declined, the share held by financial intermediaries has correspondingly risen. Intermediaries' holdings first accounted for the majority of all direct claims outstanding in the American financial markets in 1969, and they have remained the majority ever since.

Table 15 presents flow data indicating the even stronger post-war dominance of intermediaries in meeting the funds required each year by nonfinancial participants in the economy. Here the main difference from the pattern indicated in Figure 5 is that these data exclude equity capital gains, which constituted most of the increase in households' equity holdings until the late i960s and more than all of the increase since then. Apart from accumulating capital gains on equities, individuals and other private domestic nonfinancial investors have played only a small and shrinking 


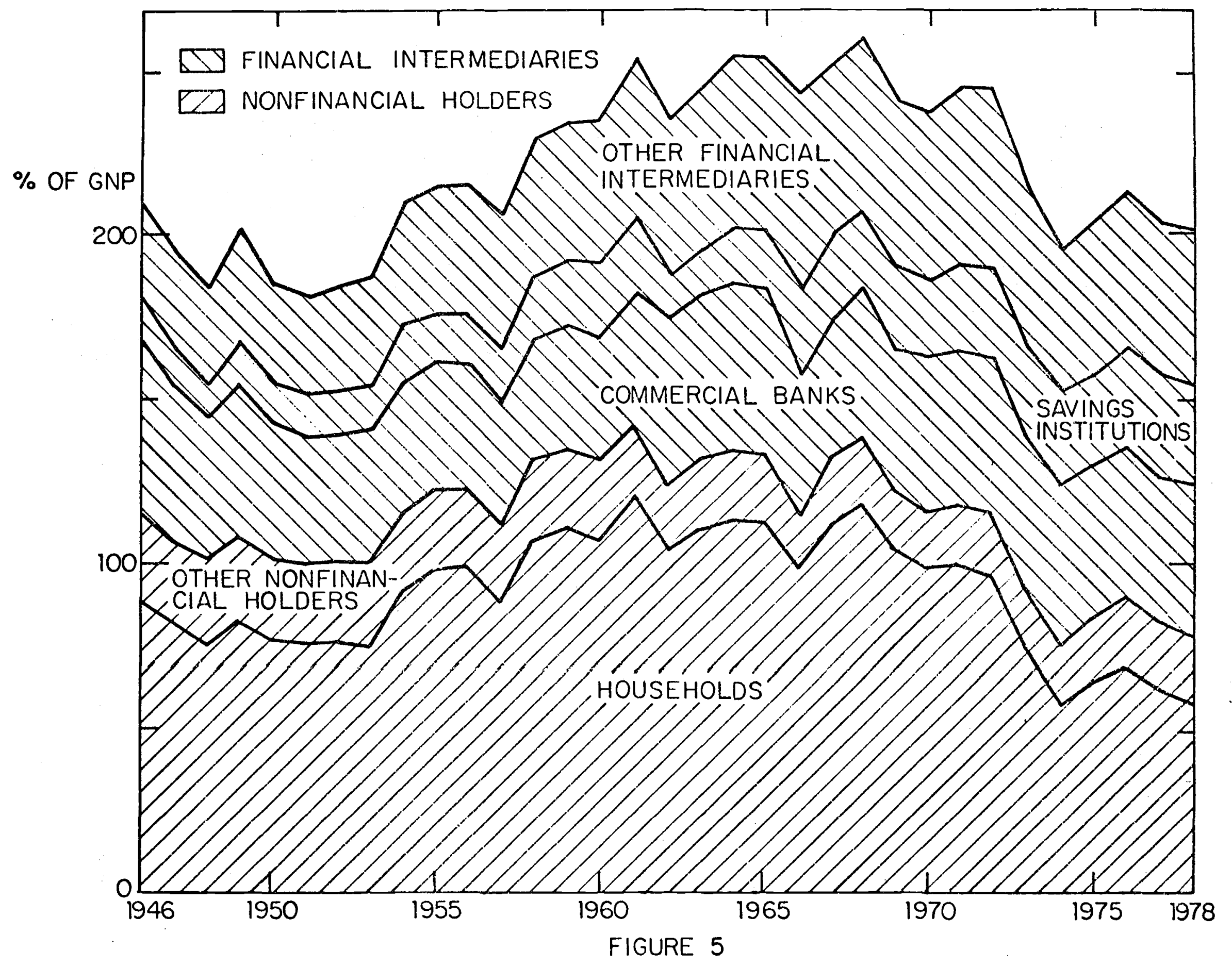

HOLDINGS OF CLAIMS AGAINST U.S. NONFINANCIAL SECTORS (INCLUDING EQUITIES) 


\section{Table 15}

\section{U.S. Credit Market Funds Advanced to Nonfinancial Sectors}

Pvt. Dom. Nonfinancial Federal

Total Investors Govt.

Financial Intermediaries

\begin{tabular}{cccc} 
Total & $\begin{array}{c}\text { Commercial } \\
\text { Banks }\end{array}$ & $\begin{array}{c}\text { Savings } \\
\text { Insts. }\end{array}$ & Other \\
\hline
\end{tabular}

Billions of Dollars

\begin{tabular}{|c|c|c|c|c|c|c|c|c|}
\hline $1946-1950$ & 14.2 & 2.3 & 1.3 & 0.1 & 10.5 & 1.3 & 2.7 & 6.5 \\
\hline $1951-1955$ & 31.4 & 5.8 & 1.7 & 0.7 & 23.1 & 6.6 & 5.8 & 10.8 \\
\hline $1956-1960$ & 40.4 & 6.8 & 2.0 & 1.3 & 30.4 & 7.7 & 8.8 & 14.0 \\
\hline $1961-1965$ & 63.1 & 1.5 & 5.1 & 1.0 & 55.7 & 20.7 & 15.0 & 20.0 \\
\hline $1966-1970$ & 94.4 & 9.7 & 8.6 & 2.2 & 73.8 & 29.4 & 14.3 & 30.1 \\
\hline $1971-1975$ & 189.0 & 18.3 & 14.0 & 10.4 & 146.3 & 60.3 & 40.2 & 45.7 \\
\hline $1976-1978$ & 338.1 & 26.7 & 23.5 & 30.8 & 257.1 & 92.0 & 76.4 & 88.7 \\
\hline
\end{tabular}

Percent of Total Funds Advanced

1946-1950

$1951-1955$

$1956-1960$

1961-1965

1966-1970

$1971-1975$

$1976-1978$

$\begin{array}{rrrr}100.0 & 16.2 & 9.2 & 0.6 \\ 100.0 & 18.5 & 5.4 & 2.3 \\ 100.0 & 16.9 & 4.7 & 3.2 \\ 100.0 & 2.3 & 8.0 & 1.4 \\ 100.0 & 10.3 & 9.1 & 2.4 \\ 100.0 & 9.7 & 7.4 & 5.5 \\ 100.0 & 7.9 & 7.0 & 9.1\end{array}$

74.0

73.7

75.2

88.2

78.2

77.4

76.0

9.1

\section{1}

19.2

45.6

20.9

18.4

34.4

19.0

21.7

34.4

31.7

31.9

31.2

15.1

24.2

31.9

21. 3

26.2

Notes: Data are averages of annua]. flows, in dollars and as percentages of annual total funds advanced. Detail may not add to totials because of rounding.

Source: Board of Governors of the Federal Reserve system. 
role in meeting directly the needs that nonfinancial entities have brought to the financial markets. ${ }^{39}$ In large part because of the growing fraction of those needs that have come in the form of debt issued by private borrowers, nonfinancial investors have instead accumulated claims on intermediaries and have left to them the task of directly allocating the economy's financial resources.

\section{B. The Role of Specific Intermediaries}

The advance of intermediation in the post-war period has hardly been uniform. The specialization of American financial intermediaries has inevitably led to some playing more important roles than others, and some experiencing more rapid growth than others, as the needs and objectives of both borrowers and lenders have changed and as government interventions have (intentionally or otherwise) favored first one kind of institution and then another.

Commercial Banks. The commercial banking system has long stood at the center of economists' interest in financial markets. Even today, despite nearly two decades of increasing emphasis on nonbank intermediaries in financial economics research, ${ }^{40}$ discussions ranging from textbook descriptions of the economy to professional evaluations of monetary policy often proceed as if commercial banks were the only intermediaries in the financial markets. This emphasis on the commercial banking system is understandable in part, in view of the special role that banks play in the monetary policy process by virtue of their relationship to the Federal Reserve system. In addition, in the past commercial banks were more dominant in financial market activity than they are today. Before World war II banks' assets and liabilities 
dwarfed those of other intermediaries, and before passage of the GlassSteagall Act in 1933 commercial banks also dominated the American securitiss business. $^{41}$ Until as recently as the early 1970s, commercial banks enjoyed a monopoly on the right to issue checkable deposits.

Since World War II the American commercial banking system has approximately held its own in relation to the scale of nonfinancial economic activity, but it has not participated in the economy's overall post-war expansion of intermediation. The approximate stability of the banking system's relative size is apparent in Figure 5, and also in the data on commercial banks' assets and liabilities presented in Table 16. The total size of the banking system in relation to gross national product has shown essentially no trend during the post-war period. Put the other way around, as Figure 6 shows, there has been little post-war trend in the "income velocity" of the broad M2 money stock, which consists of most commercial bank deposit liabilities (plus the public's currency holdings), or in the corresponding income velocity of bank credit, which consists of most commercial bank earning assets. 42 This relative stability (actually a slow decline) in the post-war period stands in marked contrast to the pre-war years when, over nearly a century, the size of the banking system continually grew in relation to gross national product. 43

Within the stability of the overall totals, however, the post-war years have also seen substantial shifts in composition on both sides of the banking system's balance sheet. Among bank assets, the most significant development of the post-war period has been the recovery of bank loan portfolios and hence the general resumption of banks' traditional role as 
Table 16

Assets and Liabilities of U.S. Commercial Banks

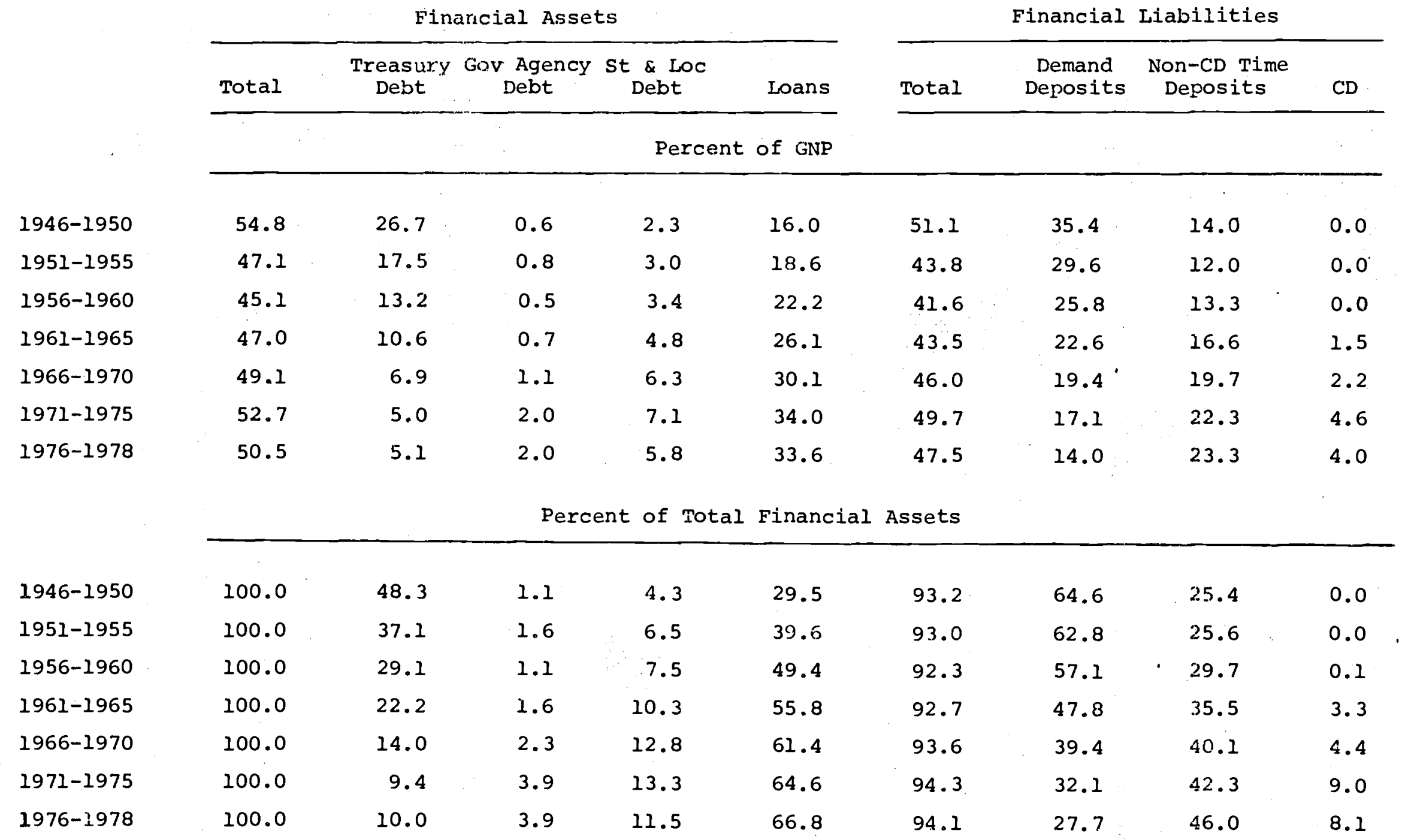

Notes: Data are averages of yearenä amounts, as percentages of annual gross national product and as percentages of annual total assets.

Detail may not add to totals because of rounding.

Source: Board of Governors of the Federal Reserve System. 


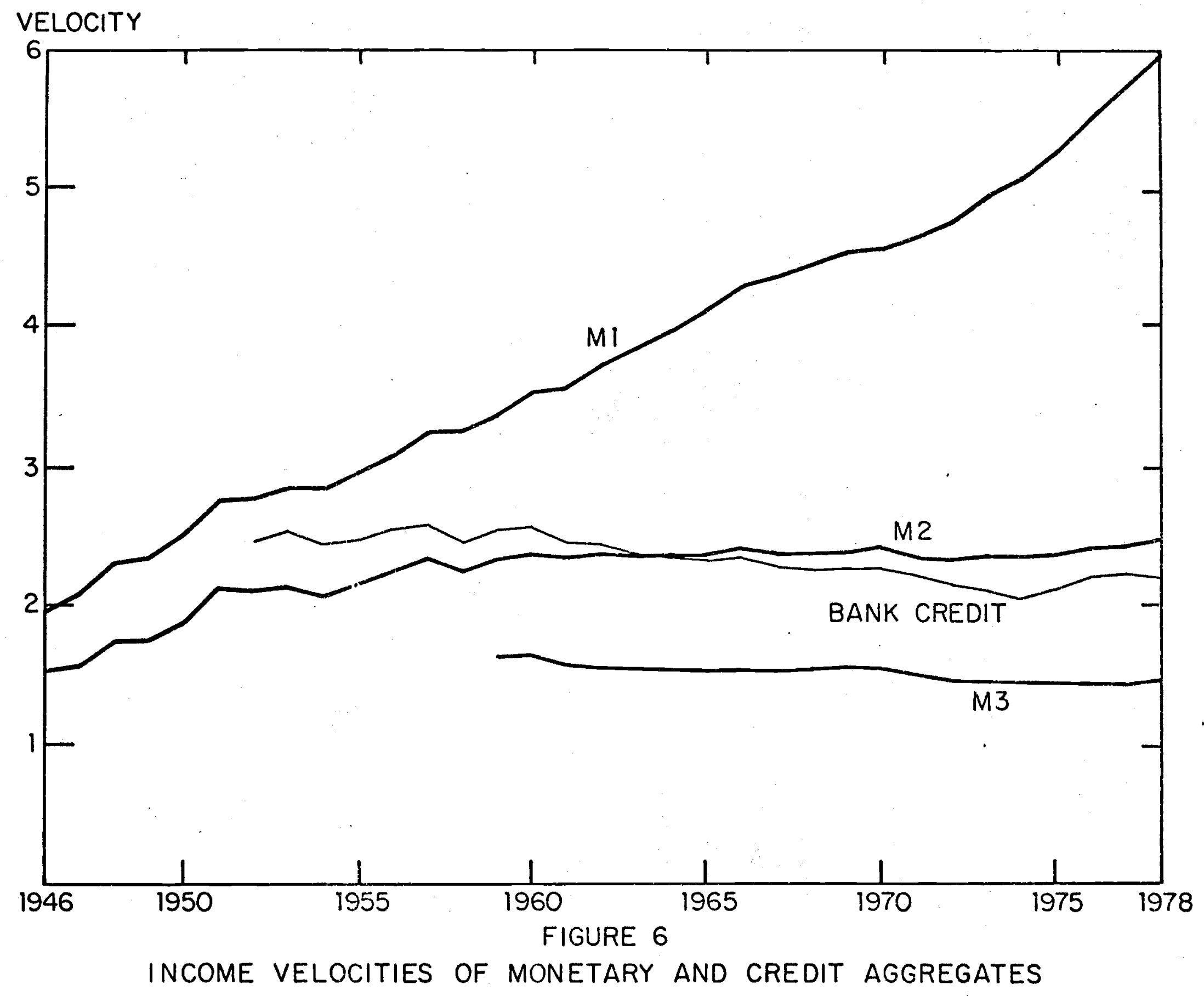


"inside" intermediaries. In 1929 loans constituted 73\% of bank credit. Luring the depression and then the war years, however, the fall-off in private debt issuing meant that, for all practical purposes, there was little or no loan business to be had. By contrast, the federal government was then issuing debt in record volume, and banks participated in financing it. By 1935 banks' securities investments exceeded their loan portfolios, and in 1945 investments constituted $79 \%$ of bank credit. Comercial banks simply were no longer very commercial. The years since 1946 have largely consisted of a reversal of the $1930-45$ pattern, with bank loans exceeding securities investments in 1957 for the first time in more than two decades and reaching $73 \%$ of total bank credit as of yearend 1978 .

In rebuilding their loan portfolios and de-emphasizing their investments, banks have also both altered the mix of their lending business and changed the character of their securities holdings. Although banks remain a principal source of business credit, and commercial and industrial loans are still the largest single category of bank lending, they no longer dominate bank loan portfolios as they once did. Instead, mortgage credit and other consumer loans now comprise nearly one-third of the total. Especially during the second half of the post-war period, the widespread use of bank-issued credit cards has been a major factor in banks' development of their consumer lending business. Moreover, among business loans per se, the larger banks have increasingly become a major factor in the intermediateterm credit market through the use of explicitly longer maturity loans (in some cases up to ten years) and revolving credits of an implicitly ongoing nature. Total bank investments have grown slowly since World War II, but because of tax incentives banks have so concentrated their investments on 
state and local government issues that, for a few years in the early 1970s, they held more of these securities than of fecieral goverrment debt. ${ }^{44}$

Among bank liabilities, the two most significant changes that have occurred during the post-war period have been the ccintinual desline of demand balances and increase of time and saving deposits, relative to either total bank liabilities or gross national product, and the "liability management revolution" that has greatly increased the larger banks' reliance on "bought funds." As Figure 6 shows, the income velocity of the narrow Ml money stock, consisting of currency plus demand deposits, has about tripled over the postwar years as a result of a combination of influences including economies of scale in the public's holding of cash balances, the secular rise in nominal interest rates, and the increasingly widespread use of credit cards and charge accounts. ${ }^{45}$ This persistent trend increase in Ml velocity stands in sharp contrast to either the absence of any trend during 1910-30 or the steeply declining trend during 1930-45. Hence only the strong growth of time and savings deposits, including the new negotiable certificates of deposit that first came into existence in 1961, has accounted for the much slower post-war increase in the income velocity of M2. Large banks' growing use of such ilabilities as certiricates of deposit, federal funds, E:arodollar borrowings, commercial paper issues, repurchase agreements and so on instruments that in some cases represent the development of new financial markets since World War II - has not only changed banks' balance sheets but also facilitated a major change in the feasible aggressiveness of bank lending practices. The enormous post-war expansion of bank loan portfolios, which banks have achieved in part through the competitive use of such devices as loan commitments and medium-term credits, would probably have been impossible 
if banks had simply continued to follow the classic practice of treating their deposits (and other liabilities) as determined by outside forces. Finally, it is useful to point out explicitly that because of changes in commercial bank organization, especially during the 1960s, the representation of banks as having merely held their own during the post-war increase in the American economy's degree of financial intermediation relative to econornic activity risks understating by a wide margin the growing overall presence of commercial banks in the financial system. After falling by more than one-half between 1920 and 1935, the number of American commercial banks has remained roughly steady at about 14,000. The number of bank branches, however, has risen from some 4,000 to over 32,000 during the post-war years, with most of this growth occurring since 1960. Moreover, especially since the 1970 Amendments to the Bank Holding Company Act, banks have increasingly gone into activities other than their traditional loan and deposit business. 46 Although their direct participation in financial intermediation has not kept pace with the rising post-war trend, commercial banks have increasingly enhanced their importance as nore nearly full-service financial institutions. Nonbank Deposit Institutions. As is clear from Figure 5, one group of intermediaries that has accounted for much of the post-war increase in American financial intermediation has been the nonbank deposit institutions including savings and loan associations, mutual savings banks, and credit unions. The public's strong demand for consumer-type time and savings deposits has kept these institutions growing rapidly, not just absolutely but in relation to economic activity, during most of the post-war period. In fact, as Figure 6 shows, their growth has even been great enough to offset the relative decline of the commercial banking system, so that the income 
velocity of the M3 money stock, consisting of 112 plus nonbank deposits, has shown a modest downward trend since the beginning of the data series in 1959. Moreover, when extrapolated backward this trend appears to have been a continuation of the downward trend associated with M2 during the pre-war era when nonbank deposit institutions were not of major importance.

Table 17 presents data for the individual deposit (or share) volume and combined asset holdings of the three major groups of nonbank deposit institutions, first in relation to gross national product and then as a share of the total assets of the three groups of institutions together. The vast post-war expansion of the savings and loan industry stands out clearly here. Between the early post-war years and the 1970 s outstanding savings and loan shares more than quadrupled as a percentage of gross national product. By 1978 the amount of these shares equaled more than twice the amount of mutual savings bank deposits and credit union shares combined, and also equaled about five-sixths of the amount of consumer-type time and savings deposits held at commercial banks. In comparison with mutual savings banks, the primary factor underlying the more rapid growth of savings and loan associations has probably been mere geography; mutual savings banks are overwhelmingly concentrated in a few states, especially New York and Massachusetts, which have experienced slower than average economic growth during the post-war period. In comparison with commercial banks, the primary factor has probably been the effect of government regulation, in that savings and loan associations did not face deposit interest rate ceilings until 1965 and have enjoved a one-fourth percent differential over commercial banks since then. The growth of credit unions has been even faster than that of savings and loan associations, but credit unions constitute another example 
Table 1.7

Assets and Liabilities of U.S. Nonbank Deposit Institutions

\begin{tabular}{|c|c|c|c|c|c|c|}
\hline & \multicolumn{3}{|c|}{ Combined Financial Assets } & \multicolumn{3}{|c|}{ Liabilities by sector } \\
\hline & & & & \multirow{2}{*}{$\begin{array}{c}\text { Savings } \\
\& \text { Loan } \\
\text { Shares }\end{array}$} & \multirow{2}{*}{$\begin{array}{c}\text { Mutual } \\
\text { Savings Banks } \\
\text { Deposits }\end{array}$} & \multirow{2}{*}{$\begin{array}{l}\text { Credit } \\
\text { Union } \\
\text { Shares }\end{array}$} \\
\hline & Total & Mortgages & $\begin{array}{l}\text { Consumer } \\
\text { Credit }\end{array}$ & & & \\
\hline & \multicolumn{6}{|c|}{ Percent of GNP } \\
\hline $1946-1950$ & 13.4 & 6.3 & 0.3 & 4.7 & 7.2 & 0.2 \\
\hline $1951-1955$ & 15.3 & 9.7 & 0.5 & 6.9 & 6.6 & 0.5 \\
\hline $1956-1960$ & 21.0 & 15.0 & 1.0 & 11.1 & 7.1 & 0.8 \\
\hline $1961-1965$ & 26.9 & 20.5 & 1.3 & 16.0 & 7.3 & 1.2 \\
\hline $1966-1970$ & 27.0 & 20.9 & 1.6 & 16.2 & 7.2 & 1.4 \\
\hline $1971-1975$ & 30.2 & 22.3 & 2.1 & 18.8 & 7.2 & 1.8 \\
\hline \multirow[t]{2}{*}{$1976-1978$} & 33.1 & 23.6 & 2.6 & 21.7 & 6.7 & 2.3 \\
\hline & \multicolumn{6}{|c|}{ Percent of Total Combired Financial Assets } \\
\hline $1946-1950$ & 100.0 & 47.4 & 2.2 & 32.3 & 53.5 & 1.8 \\
\hline $1951-1955$ & 100.0 & 63.4 & 3.3 & 41.2 & 43.0 & 3.0 \\
\hline $1955-1960$ & 100.0 & 71.4 & 4.4 & 50.0 & 33.9 & 4.0 \\
\hline $1961-1965$ & 100.0 & 76.4 & 5.0 & 54.7 & 27.1 & 4.4 \\
\hline $1965-1970$ & 100.0 & 77.3 & 6.0 & 54.5 & 26.6 & 5.2 \\
\hline $1971-1975$ & 100.0 & 73.9 & 7.0 & 56.0 & 23.5 & 6.2 \\
\hline $1976-1978$ & 100.0 & 71.4 & 8.0 & 58.4 & 20.2 & 7.0 \\
\hline
\end{tabular}

Notes: Data are averages of yearend amounts, as percentages of annual gross national product and as percentages of arnual total assets.

Detail may not add to totals because of rounding.

Source: Board of Governors of the Federal Reserve System. 
of rapid growth from a small base, and they remain by far the smallest of the three groups of institutions. Mutual savings banks are alone among the three groups in having failed to do more than grow in pace with economic activity. Although mutual savings banks were twice as large as savings and loan associations at the end of world War II, savings and-loans were equal in size in 1954 and more than three times as large by 1978.

Because all of these nonbank deposit institutions operate under legal and regulatory constraints governing the disposition of their asset portfolios, their aggregate contribution to meeting the financial needs of nonfinancial participants in the economy has followed a fairly predictable pattern. Savings and loan associations and mutual savings banks typically invest some $80 \%$ and $70 \%$ of their assets in mortgages, respectively, so that these two groups together have become the nation's leading provider of mortgage lending. As of yearend 1978 savings and loans and mutual savings banks together held $45 \%$ of all outstanding mortgages (in comparison to $18 \%$ for commercial banks, the next largest class of holders). These institutions are especially predominant in the market for single-family home mortgages, accounting for $55 \%$ of yearend 1978 loans outstanding. Credit unions, by contrast, have traditionally invested most of their assets in consumer installment loans, and by 1978 they accounted for $14 \%$ of the outstanding consumer credit.

As the discussion in Section IV below emphasizes, the history of American nonbank deposit institutions in the post-war period has been in large part a story of evolving financial regulation, including restrictions on these intermediaries' liability issuing as well as their asset holding. In this context, what may well turn out to be two of the most important 
changes affecting nonbank financial institutions within the post-war era are only just in progress at the time of writing. The first is the sudden acceleration of the erosion of the deposit interest rate ceilings these institutions have faced since the mid 1960s, following the introluction in mid 1978 of "money market certificates" bearing yields set in relation to those on Treasury bills. Just by late 1979 - that is, after less than eighteen months - these new deposit certificates accounted for more than one-fourth of all deposits at savings and loan institutions and almost onefourth at mutual savings banks. The second change is the expansion of authority to issue interest-bearing checkable deposits, which nonbank deposit institutions and commercial banks in the New England states received in several steps during 1972-76, and the extension of which to the rest of the country is to be decided by congress by 1980. Both checking account authority and the freedom from deposit interest rate ceilings are likely to increase greatly the demand for claims on nonbank deposit intermediaries, although the impact of the latter on these institutions' cash flows (and even solvency in some cases) makes it a mixed blessing in the short run.

Nondeposit Intermediaries. Finally, as is also apparent from Figure 5 , a significant part of the post-war increase in the American economy's degree of financial intermediation has stemed from neither commercial banks nor nonbank deposit institutions but, instead, from intermediaries that issue only nondeposit claims. There are many forms of such intermediaries operating in the American markets, but the most familiar and important among them include life and casualty insurance companies, private and public sector pension funds, independent consumer finance companies and the "captive" finance companies of nonfinancial businesses, equity and money market mutual 
funds, real estate investment trusts, and security brokers and dealers. Table 18 presents data, analogous to that shown above for the nonbark deposit institutions, for three specific categories of nondeposit intermediaries: ${ }^{47}$ life insurance companies, private pension funds, and state and local government pension funds. The reason for focusing in particular on these three groups is not only that they are the largest of the nondeposit intermediaries but also that their respective post-war experience reflects some interesting contrasts. Because the low interest rates implicitly paid on the savings component of ordinary life insurance has increasingly favored the use of group and other term insurance policies, life insurance companies' total assets held and liabilities outstanding grew little relative to gross national product during the first half of the post-war period, and since then they have been declining in relative terms. Moreover, the relative decline in these companies' life insurance business has been even more pronounced, in that their growth in recent years has consisted disproportionately of pension mories which they manage for other businesses. As of yearend 1978 pension reserves constituted nearly one-third of life insurance companies' total liabilities, up from less than one-terth in the early post-war $y$ ears. By contrast, both private and public sector pensions have experienced extraordinarily rapid growth throughout these years. Tax incentives at both the individual and corporate levels, business personnel policies aimed at reaucing worker turn-over, features of the collective bargaining process, and other corporate financial objectives have all combined to favor the mushrooming of private pension liabilities since World war II. During most of this period, however, businesses had (and many used) broad latitude to incur pension liabilities without funding them. The 1974 Employee Retirement 
Income Security Act has subsequently specified minimum standards for the vesting of workers' rights to accumulated pension benefits and for employers' funding of vested pension liabilities. ${ }^{48}$ Even so, businesses still have flexibility in choosing the actuarial assumptions underlying the calculation of future benefits, the minimum required amortization of unfunded vested benefits is very slow, and nonvested benefits require no funding at all. Consequently, many businesses continue to carry substantial amounts of unfunded liabilities, so that private pension funds' total assets as shown in Table 18 substantially understate their liabilities. 49 This understatement has been especially great during the 1970 s when many private pension funds' asset portfolios, of which in the aggregate about two-thirds is invested in equities, have suffered an erosion in market value.

State and local government pensions, including both teachers' and other employees' funds, have experienced similar post-war growth. Public sector workers have the same tax incentive to use the persion mechanism to spread income beyond retirement as do private sector workers. Although public sector employers do not have the same tax incentives as do private businesses, in many cases the political process nas probably favorea the use of pension compensation over current compensation, especially when there is no pressure to raise tax or other revenues immediately to fund the accumulating pension liabilities. In fact public sector pension funds have been and remain substantially underfunded, so that the asset data shown in Table 18 greatly understate their liabilities also. ${ }^{50}$ The continued growth of public sector pensions' assets during the 1970s, in contrast to private pensions, reflects merely the smaller share of assets invested in equities (about onethird in the aggregate) rather than any difference in funding practices. 
The asset mix of these insurance and pension intextrediaries - and hence their role in financing economic activity - has also undergone important changes since World War II. Regulatory changes in the 1960s allowed many life insurance companies to increase the equity portion of their portfolios, and since the mid 1960s life insurers have largely withdraw from direct home mortgage lending. State and local government pension funds and especially private pension funds have even more dramatically increased the equity share of their investments. Consequently, these nondeposit intermediaries have increasingly become a major source of both debt and equity funds for corporate businesses. As a result of these portfolio changes, together with the rapid growth of pensions and the (relative) stagnation of the commercial banking system, insurance companies and pension funds combined have increasingly dominated banks as holders of claims on the American corporate business sector - despite banks' post-war emphasis on loans over investments in government securities. In the early post-war years these intermediaries held only slightly more claims on the corporate sector than did commercial banks, but by the 1970 s they held more than twice as much.

It is also important to distinguish the claims on business held by banks, which are overwhelmingly in the form of short- to medium-term loans, from the corresponding claims held by insurance companies and pension funds, which consist mostly of long-term debt and equity securities. These nondeposit intermediaries have traditionally held some three-fourths of all outstanding corporate bonds, and in recent years they have also come to hold nearly one-sixth of all corporate equity. The flow data shown in Tables 19 and 20 give a further idea of these investors' importance in providing long- 


\section{Table 18}

Assets of U.S. Life Insurance Companies and Pension Funds

Combined Financial Assets

\begin{tabular}{lccc}
\hline Total & Equities & $\begin{array}{c}\text { Corporate } \\
\text { Bonds }\end{array}$ Mortgages \\
\hline &
\end{tabular}

Financial Assets by sector

\begin{tabular}{|c|c|c|}
\hline $\begin{array}{l}\text { Iife } \\
\text { Insur. Co. }\end{array}$ & $\begin{array}{l}\text { Private } \\
\text { Pension }\end{array}$ & $\begin{array}{l}\text { State \& Local } \\
\text { Gov. Pension }\end{array}$ \\
\hline
\end{tabular}

\begin{tabular}{|c|c|c|c|c|c|c|c|}
\hline $1946-1950$ & 24.6 & 0.8 & 8.2 & 4.3 & 21.2 & 1.9 & 1.4 \\
\hline $1951-1955$ & 26.3 & 1.6 & 10.8 & 6.5 & 20.8 & 3.3 & 2.2 \\
\hline $1956-1960$ & 31.8 & 3.4 & 13.2 & 8.3 & 22.3 & 6.2 & 3.3 \\
\hline $1961-1965$ & 36.0 & 6.1 & 14.3 & 9.1 & 22.3 & 9.2 & 4.5 \\
\hline $1966-1970$ & 36.8 & 8.3 & 14.0 & 9.0 & 20.6 & 10.8 & 5.4 \\
\hline $1971-1975$ & 35.1 & 10.2 & 12.9 & 6.7 & 18.4 & 10.4 & 6.4 \\
\hline $1976-1978$ & 33.3 & 8.7 & 12.9 & 5.5 & 17.3 & 9.2 & 6.8 \\
\hline
\end{tabular}

Percent of Total Combined Financial Assets

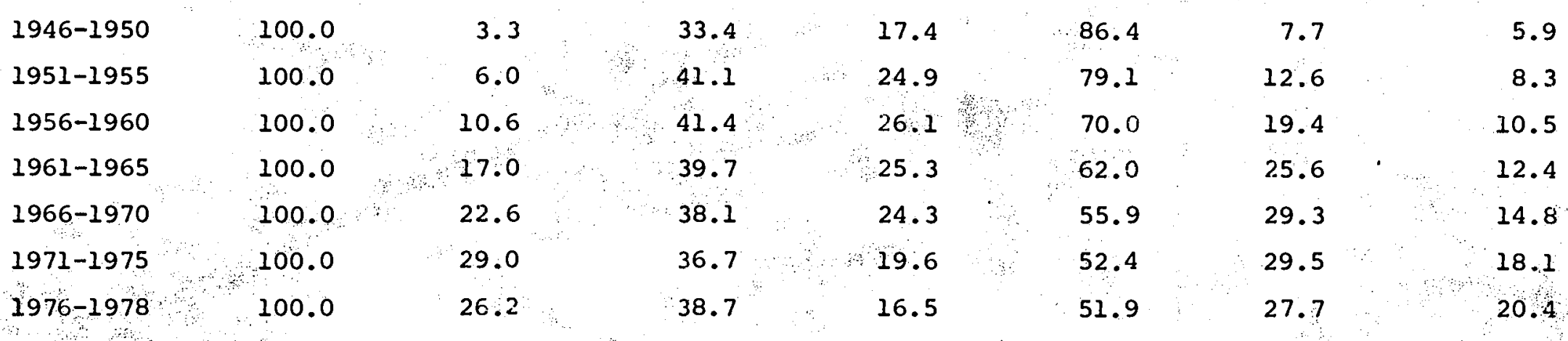

Notes: Data are averages of yearend amounts, as percentages of annual gross national product and as percentages of annual totalissets.

Detail may not add to totals because of rounding.

Source: Board of Governors of the Federal Reserve system. 
Net Issues and Purchases of U.S. Corporate Bonds

\begin{tabular}{|c|c|c|c|c|c|c|}
\hline & \multicolumn{2}{|c|}{ Net Issues } & \multicolumn{4}{|c|}{ Net Purchases } \\
\hline & Total & $\begin{array}{c}\text { Domestic } \\
\text { Nonfinancial } \\
\text { Businesses }\end{array}$ & Total & $\begin{array}{l}\text { Iife } \\
\text { Insurance } \\
\text { Companies }\end{array}$ & $\begin{array}{l}\text { Private } \\
\text { Pension } \\
\text { Funds }\end{array}$ & $\begin{array}{l}\text { State \& Local } \\
\text { Government } \\
\text { Pension Funds }\end{array}$ \\
\hline & \multicolumn{6}{|c|}{ Billions of Dollars } \\
\hline $1945-1950$ & 2.9 & 2.5 & 4.0 & 2.7 & 0.4 & 0.1 \\
\hline $1951-1955$ & 4.1 & 3.5 & 3.9 & 2.4 & 1.0 & 0.4 \\
\hline $1956-1960$ & 5.9 & 4.4 & 4.7 & 2.2 & 1.6 & 0.9 \\
\hline $1961-1965$ & 6.4 & 5.0 & 6.0 & 2.6 & 1.4 & 2.0 \\
\hline $1966-1970$ & 15.9 & 13.9 & 7.5 & 2.6 & 1.3 & 3.6 \\
\hline $1971-1975$ & 23.1 & 17.4 & 12.9 & 6.3 & 1.3 & 5.3 \\
\hline \multirow[t]{2}{*}{$1976-1978$} & 35.0 & 21.3 & 27.8 & 17.6 & 3.7 & 6.5 \\
\hline & \multicolumn{6}{|c|}{ Percent of Total Net Issues } \\
\hline $1945-1950$ & 100.0 & 87.8 & 139.9 & 93.8 & 15.1 & 3.1 \\
\hline $1951-1955$ & 100.0 & 86.6 & 95.6 & 60.7 & 24.6 & 10.3 \\
\hline $1956-1960$ & 100.0 & 75.1 & 79.4 & 37.6 & 26.8 & 15.1 \\
\hline $1961-1965$ & 100.0 & 70.8 & 94.5 & 40.6 & 22.0 & 31.8 \\
\hline $1966-1970$ & 100.0 & 87.7 & 47.5 & 16.5 & 8.5 & 22.5 \\
\hline $1971-1975$ & 100.0 & 75.2 & 55.7 & 27.1 & 5.4 & 23.1 \\
\hline $1976-1978$ & 100.0 & 50.9 & 79.5 & 50.4 & 10.5 & 18.6 \\
\hline
\end{tabular}


Net Issues and Purchases of U.S. Corporate Equities

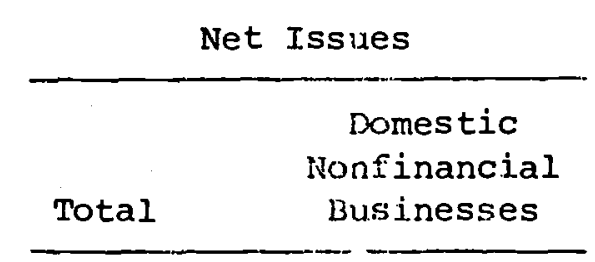

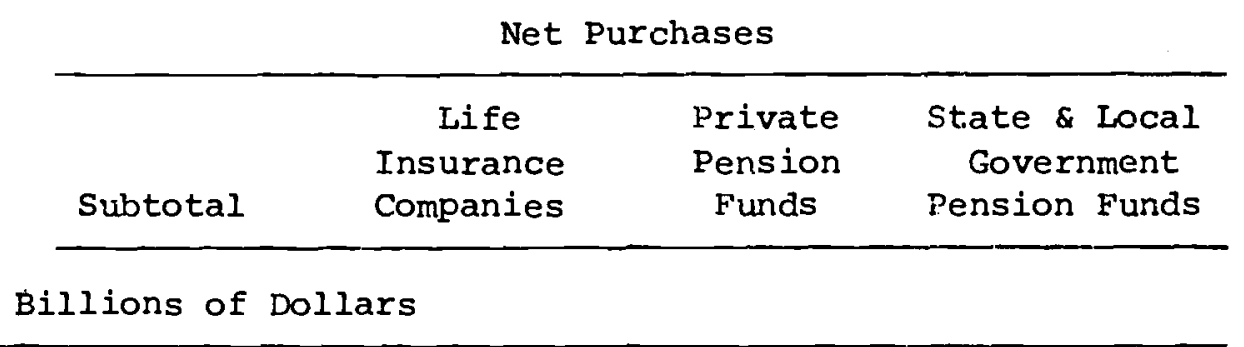

\begin{tabular}{|c|c|c|c|c|c|c|}
\hline $1946-1950$ & 1.2 & 1.1 & 0.4 & 0.2 & 0.2 & 0.0 \\
\hline $1951-1955$ & 2.2 & 1.9 & 0.6 & 0.1 & 0.5 & 0.0 \\
\hline $1956-1960$ & 2.4 & 2.0 & 1.6 & 0.1 & 1.4 & 0.1 \\
\hline $1961-1965$ & 1.1 & 0.7 & 3.1 & 0.5 & 2.4 & 0.2 \\
\hline $1966-1970$ & 3.4 & 2.5 & 7.1 & 1.3 & 4.6 & 1.3 \\
\hline $1971-1975$ & 10.7 & 8.8 & 11.9 & 3.0 & 5.9 & 3.0 \\
\hline $1976-1978$ & 7.5 & 5.3 & 10.2 & 1.4 & 5.7 & 3.2 \\
\hline
\end{tabular}

Percent of Total Net Issues

\begin{tabular}{|c|c|c|c|c|c|c|}
\hline $1946-1950$ & 100.0 & 92.8 & 31.8 & 16.6 & 14.8 & 0.3 \\
\hline $1951-1955$ & 100.0 & 86.6 & 31.6 & 5.9 & 24.9 & 0.9 \\
\hline $1956-1960$ & 100.0 & 82.8 & 66.5 & 5.5 & 58.6 & 2.5 \\
\hline $1961-1965$ & 100.0 & 60.5 & 310.9 & 44.4 & 221.5 & 21.9 \\
\hline $1966-1970$ & 100.0 & 73.3 & 206.8 & 36.8 & 132.7 & 37.2 \\
\hline $1971-1975$ & 100.0 & 82.7 & 111.6 & 27.9 & 55.3 & 28.5 \\
\hline $1976-1978$ & 100.0 & 70.4 & 136.2 & 18.0 & 75.9 & 42.2 \\
\hline
\end{tabular}

Notes: Data are averages of anrual flows, in billions of dollars and as percentages of total net issues. Detail may not add to totals because of rounding.

Source: Board of Governors of the Federal Reserve System. 
term debt and equity capital to American business corporations. In addition to accounting for much or all of the corporate sector's net long-term bond financing throughout the post-war period, since 1960 they have also accounted for more than all of its equity Financing, absorbing also the equity holdings liquidated by the household sector. In sum, businesses' equity and bond financing has become increasingly dominated by these investors. Given their high rates of portfolio turn-over, especially in comparison with individuals, equity and bond trading has become even more so.

\section{Financial Innovation and the Advance of Market Efficiency}

With individuals doing less of the direct lending in the American financial markets and specialized intermediaries doing more, it is not surprising that many aspects of the working of these markets have changed during the post-war years, and that most of these changes have tended to reduce or eliminate barriers to the transfer of financial resources and thereby to render the financial system more efficient than before. One example of this evolution has been individuals' increasing ability to diversify their holdings via mutual funds, pensions and mortgage pools. Another has been their increased ability to escape interest rate ceilings via negotiable certificates of deposit or money market certificates, and minimum size requirements via money market mutual funds. Still another has been their ability to invest abroad (or for businesses to borrow abroad) as legal barriers have fallen. Especially in conjunction with innovations exploiting new physical technologies, post-war changes in financial intermediation have reduced many of the barriers and frictions that interfere with the capital allocation process.

At least four kinds of friction reducing changes bear explicit attention. 
First, wholly apart from the effective reduction of transactions costs associated with increased intermediation, marginal transactions costs in both the direct and the indirect senses have fallen irregularly throughout the post-war period. The fee typically charged for negotiated underwritings of high grade corporate bonds, for example, declined from $\$ 10$ or more per $\$ 1000$ bond in the early post-war years to $\$ 8.75$ per bond in the late 1950 s and has remained unchanged at that level ever since, although underwriting fees for competitively bid bond issues have fallen more substantially in recent years. Bid-asked spreads have fallen from $\$ 2.50$ or $\$ 5.00$ to $\$ 1.25$ or even $\$ 0.625$ per bond for actively traded government bonds, and the feasible size of transaction at the quoted prices has increased substantially for both government and corporate bonds. Bid-asked spreads for equity issues traded on the New York Stock Exchange have also declined to a typical $\$ 0.25$ or $\$ 0.125$ per share for most issues, instead of the $\$ 0.375$ per share that was more prevalent some years ago. Effective equity brokerage fees have typically fallen as well, especially for larger trades, although under the fixed minimum commission system the reductions usually took the form of indirect rebates and services provided. Since the Securities and Exchange Commission prohibited fixed minimum commission rates in 1975, average fees on large trades have fallen from $\$ 0.15$ per. share to only $\$ 0.08$ per share $(0.4 \%$ of principal value). Overall, as a result of natural competitive forces in the financial markets, striking advances in electronic communications and data processing technology, and specific regulatory actions, these and other direct transactions costs have fallen sufficiently that the markets for what are traditionally regarded as "nonliquid" instruments now in fact provide substantial liquidity. 51 . In addition, indirect transactions costs at the margin have fallen during the post-war period as nonfinancial businesses have increasingly invested in 
sophisticated financial staffs, either "in-house" or on a retainer basis, and individuals have gained substantially more financial knowledge also.

A second change which has been related to the decline in transactions costs, and which has also served to make markets both more liquid and more efficient in the sense of reducing barriers to financial allocations and re-allocations, has been the increasing trend toward negotiability of financial assets. As table 21 shows, nonfinancial corporations and finance companies have on balance increased the negotiability of - and hence the potential market for - both their short-term and their long-term debt by substituting commercial paper issues for bank loans and publicly offered bonds for directly placed bonds. In addition, a large part of the post-war trend toward negotiability of financial assets has occurred through the development of new financial instruments. Commercial banks first introduced the negotiable certificate of deposit in 1961, and by the mid 1970s these certificates accounted for some one-tenth of banks' total liabilities. Bank lending has also become more of a straightforward market transaction and less closely tied to bank-customer relations, as in many cases commitment fees have augmented or replaced deposit balances as criteria for extending credit, and the greater flexibility provided by banks' liability management practices has better enabled them to accommodate fluctuating business credit demands (especially through the use of floating-rate loans). The introduction of exchange-traded options and financial futures markets has facilitated hedging and speculating investment postures that previously were either impossible to achieve or possible only via expensive combinations of long and short positiens. The development in the 1960s of a secondary mortgage market, and the advent of mortgage-backed "pass-through" securities, has also rendered home mortgages in effect negotiable and has correspondingly increased the 
Table 21

Negotiability of U.S. Corporate Debt

Net Corporate Bond Issues

\begin{tabular}{cc} 
Percent & Percent \\
Privately & Publicly \\
Placed & . Offered \\
\hline
\end{tabular}

$1946-1950$

1951-1955

$1956-1960$

$1961-1965$

$1966-1970$

$1971-1975$

$1976-1978$
46.7

49.4

41.3

55.6

33.0

27.3

72.7

57.9

58.7

44.4

67.0

42.1
Net Change in Bank Loans \& Commercial Paper

\begin{tabular}{cc}
\hline Percent. & Percent \\
Bank & Commercial \\
Loans & Paper \\
\hline
\end{tabular}

95.7

4.3

92.8

7.2

92.1

7.9

88.4

11.6

81.1

18.9

81.6

18.4

78.8

21.2

Notes: Data are percentages of the respective totals. 
range of investors prepared to consider tinem.

The gradual and piecemeal rsmoval of international barxiers to finarcial transactions, including the American actions already noted aoove as well as corresponding actions by other countries, has been a third importart factor. in the post-war development of the American - indeed, the world -. finaricial. system. One part of this process has simply been the development cf viable financial markets abroad. Most European countries did not even have currency converibility for current transactions until 1958 (Japan not until 1964). Convertibility for financial transactions has come in individual pieces since then, and it is still incomplete although there is now so much convertibjlity that massive short-run movements of short-term capital inave become a major problem in the international. monetary system. Since tie removal of the American capital controls, both American and foreign borrowers may again choose whether to raise funds in the American martets or abroad, Anerican banks may choose between domestic and foreign loans, anı̈ otiler American investors may choose whether to buy securities issued at home or abroad. Other countries have also gradually eliminated analogous capital controls - most recently the United Kingdom just in 1979. All of tirese developments have improved the markets' ability to allocate financial rescurces in comparison with the earlier situation in wich banks' participation in the Eurodollar market was the primary vehicle for international capital flows, or even more the situation of the still earlier post-war years before the reopening of foreign financial markets and the use of modern communications technology to connect them with the American markets. In addition, as the example of around-the-clock trading in Eurodollars and Asian dollars suggests, the removal of international financial barriers has also even further enhanced the overall negotiability of many financial assets. The move to floating 
exchange rates in the 1970s, a subject that lies beyond the scope of this essay, has also been an inportant part of this entire set of developments. 52

Financial innovation per se - whether due to tecinological, regulatory, or entrepreneurial forces - has constituted a fourth major source of postwar change enhancing the efficiency of the American financial system. Given its low capital intensity and highly mobile (and well educated) labor force, the financial industry is typically able to adopt innovations both more cheaply and more rapidly than can, for example, manufacturing or other production lines of business. 53 Many of the innovations that have been so important. in changing the structure and working characteristics of the American financial markets have already appeared in the discussion above. other examples include such now standard instruments as leveraged leases, variable-rate annuities, corporate bonds subject to call protection, and floating-rate debt issues, as well as instruments that are only just now coming into use like graduated-payment and variable-rate mortgages. Additional markets like those for federal funds and commodity futures are not new in the post-war period, but they now play a far greater role in the financial system than ever before. Adoption of modern electronic technology has already facilitated such innovations as remote terminal banking, and far reaching structural changes like the development of a semi-automated national market system for equity trading, or the introduction of an electronic funds transfer system for commercial banking, are now visible on the horizon though not yet in place. In every case, these innovations have acted to reinforce the continual trend toward erosion of barriers and frictions that has marked the evolution of the American financial markets since World War II. Despite this cataloguing of the reduction of costs and barriers that have followed from the rise of intermediation together with innovation, 
however, it would be misleading to suggest that the American financial system has yet (or vill soon) realize economists' idealized conception of a perfectly efficient mechanism for allocating financial resources. Many imperfections remain. Perhaps the most striking example of the American financial markets' continuing shortcomings in this respect is the failure, despite the experience documented in Table 14 , to provide an investment vehicle that would (presumably, for a price) guarantee the purchasing fower of its holder's capital value. ${ }^{54}$ In addition, the home mortgage instrument remains a relatively inflexible instrument despite recent innovations, ${ }^{55}$ tax lock-ins remain important despite the changes in inheritance taxes in 1976 and in capital gains taxes in 1978, pension rights remain entirely illiquid, and most individuals face severe liquidity constraints preventing their borrowing against future income in the form of either wages or pension benefits. More generally, the gais between the interest rates that most individuals earn on assets and pay on borrowings is very wide. In sum, the post-war trend has indeed been toward more efficient markets, but at least as of 1979 there is much room left for further development. 
IV. Changes in the Role of Government

In addition to its reiliance on the financial markets as a borrower financing its current deficit, the federal government has played a number of other roles in the development of the American finencial markets since World War II. Regulatory actions and tax policies have resulted in significant impacts on how the financial markets have been able to do their job. The government's activities as a financial intermediary have affected the allocation (and perhaps the total) of saving in the economy. The monetary policy carried out by the Federal Reserve system has fundamentall: shaped the post-war course not only of the finaricial markets but of the economy as a whole. In sum, despite the decline of the government's role as a direct borrower, the broader changes at work during the post-war era have probably been in the direction of a growing overall influence of government on the American financial markets.

\section{A. Deposit Insurance and Government Regulation}

The proliferation of the federal government's regulatory activities since world war II has touched almost every part of the American econony, and has brought important and far reaching changes. 56 The financial markets have been no exception in this regard. Some of the most significant innovations in financial market regulation came during the 1930s, as part of the society's immediate reaction to the excesses of the 1920 s and their effects during the depression. Others have come since the war. On both counts, however, the post-war experience has been significantiy different from what went before.

The single most important development along these lines during this 
century has been the almost universal adoption of deposit insurance following the inception of both the Federal Deposit Insurance Corporation (EDIC) and the Federal Savings and Loan Insurance Corporation in 1934 . Before 1934 the inaividual depositor had always to regerd $h_{i s}$ deposit holdings as assets subject to default risk, and the wave of bank failures during the early 1930 s dramatically demonstrated the potential impact of default rot only on individuals' perceptions, and hence their asset holding behavior, but also on nonfinancial macroeconomic outcomes. After 1934 depositors' losses due to bank failure shrank quickly to miniscule proportion. Bank failures and forced mergers, of which there were hundreds each year during the i920s and more than 1,000 in each year during 1930-33 (over 4,000 in 1933 alone), suddenly shrank to the double-digit range in 1934 and into single digits per year by the end of World war II. Moreover, from 1934 until the mid 1970s what few bank failures did occur were entirely concentrated among banks with less than $\$ 100$ million in deposits, and nearly three-fourths of all failures were among banks with less than $\$ 1$ million in deposits. ${ }^{57}$ Even then, more often than not - and especially when a large bank has failed, as in 1974 - the FDIC has arranged either for a merger or for the assumption of the failed bank's valid assets (and a corresponding share of its liabilities) by another bank, rather than simply pursuing liquidation, so that depositors have suffered no loss of liquidity at all. Even in cases of liquidation, the FDIC has typically settled deposj.tors' claims almost immediately. In sum, the advent of deposit insurance has fundamentally changed the nature of the American financial markets.

Federal regulation of banking has not been limited to that incidental to the insurance of deposits. The Federal Reserve System, the FDIC and the Comp- 
troller of the Currency have shared with the individual state banking commissions the responsibility for regulation and supervision of commercial banks. Important aspects of these activities include inspecting bank operations (and in particular, the composition of bank portfoliosl, ruling on bark merger applications, and regulating the entrance of banks and bank holding com:uaries into activities beyond traditional banking businesses. Because the fixedpercentage pricing system for deposit insurance impiicitly acts as a subsidy to risk taking, it is possible that the role of bank inspection has been especially important in limiting the risk level of banking, although the available eviderice is anbiguous on this question. ${ }^{58}$ Bank inspections have in any case become more relevant for limiting risks as banks have moved heavily into international transactions like exchange market trading and foreign lending. In addition, control over banks' applications to engage in nonbanking activities has become more important as banks and their holding companies have increasingly widened their scope to encompass leasing, credit cards, real estate, insurance and other related activities.

Growth of federal regulation in the post-war era has also extended beyond barks and other deposit intermediaries. The securities legislation of the 1930s, including especially the National Banking (Glass-Steagall) and Securities Acts of 1933 and the Securities and Exchange Act of 1934, not only created a separate securities industry distinct from the commercial banking system but also set down an elaborate set of rules governing securities issuing and trading and established the Securities and Exchange Commission to enforce them. This legislation of course antedated world war II, but many of its effects have appeared only after the war. Disclosure requirements increased, and have continued to increase throughout the post-war years. 
Public utility companies from 1941 and railroads from i 944 were compelled to seek competicive bids on their new securities - - a practice which over. time brought major changes in the structure of the investment banking industry. ${ }^{59}$ Margin requirements for securities tradirg, set by the Federal Reserve under authority of the 1933 Act, have remained at or above 50\% since World War II - an especially sharp contrast to the experience of the 1920s. Under the Investment Advisor Act of 1910, the regulation of the post-war securities industry has extended also to asset management as well as the trading and issuing functions. As of the time of writing, the securities and Exchange Commission is actively considering plans to restructure securities trading so as to develop the nationwide market system mandated by Congress in 1975, and it is possible that the implementation of such a system would eventually even result in a dealer market's roplacing the auction market that has characterized most American stock exchanges for nearly two centuries.

Feceral regulation of the financial markets has also affected nondeposit intermediaries other than securities brokers and dealers. The most recent development along these lines, which bears potentially important implications not just for the financial markets but also for the overall amount and composition of saving in the American economy, is the regulation of private pension funds under the Employee Retirement Income security Act of 1974. In addition to the minimum pension funding standards already discussed in Section III, this legislation further specified associated fiduciary responsibilities for the management of pension funds' assets. Even within the first few years it has had a noticeable impact on both the anount of pension funding and the composition of pension investments. Given the 
already increasing role of private pensions in post-war financial intermediation, as discussed above, these changes are of. great potential significance for the future.

\section{B. New Distortions in the Allocative Mechanism}

It would be surprising if the increase since world war II in the presence of government, both in the financial markets and more broadly in the economy as a whole, had not brought with it at least some distortions in the economy's allocative mechanism. In fact, as the post-war period has advanced, government actions have directly or indirectly introduced numerous distortions in the financial system's allocation of capital. Several of these distortions, like the restrictions on international capital flows, have already figured in the discussion of sections II and III. Nevertheless, it is important to note specifically two aspects of the distortion of capital allocations that have been particularly important since World War II and have differentiated this period from the pre-war experience.

The National Banking Act of 1933 introduced deposit interest rate ceilings, in part as a response to banks' alleged overly aggressive bidaing for interbank demand deposits during the 1920s. The ceilings have also applied to other demand deposits as well as time and saving deposits, however, so that they have also served as an anti-competitive device to subsidize bark profits and bank borrowers at the expense of bank depositors. Given the post-war changes in the pattern of deposit holding reviewed in section III, the main focus of these ceilings, imposed under the Federal Reserve's Regulation $Q$ and analogous regulations governing nonbank intermediaries, came to be consumer-type time and savings deposits. Moreover, given the growirg 
role of nonbank intermediaries both in issuing such deposits and in mortgage lending, the subsidy has mostly either passed to homewners or bolstered the lending institutions' (usualiy inaccessible) reserves. 60

Apart from the long-run average subsidy transferred from depositors to mortgage borrowers, however, the chief effect of deposit interest rate ceilings has been the introduction of severe volatility into both intermediation and homebuilding through the interaction of these ceilings with the cyclical pattern of short-term interest rate movements. A wholly new post-war phenomenon, experienced for the first time when interest rates on readily available open market investment instruments rose above the prevailing savings deposit ceilings in 1960, was the widespread witharawal of deposits from both banks and nonbank deposit intermediaries. This "disintermediation" then led to reduced mortgage lending, which after some lag led in turn to a decline in residential construction activity. As Figure 7 shows, this patiern has subsequently recurred in 1969-70 and in 1973-74, with increasing severity except that in more recent episodes governmentsponsored intermediaries have increasingly supplemented the funds lost to the mortgage market. Nevertheless, the net result has been the introduction of sufficient volatility into the residential construction industry thet the decline in housing activity induced in this manner has typically been a major element in post-war economic downturns.

The second major post-war distortion in the financial markets' capital allocation mechanism has come from taxes, and in particular from the interaction of taxes with the more rapid price inflation of the later post-war years. The federal government was constitutionally prohibited from imposing income taxes until after passage of the Sixteenth Amendment in 1913 , 

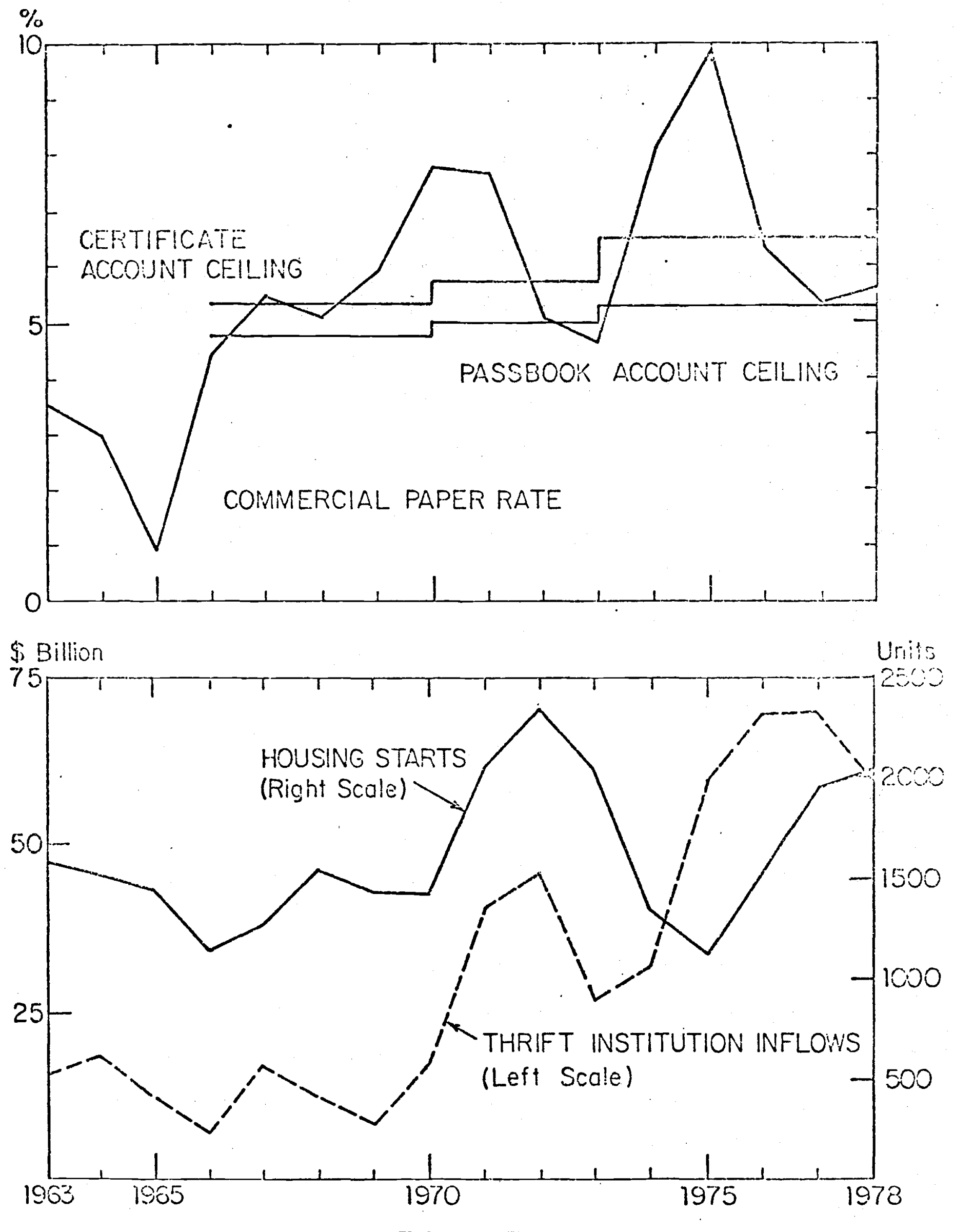

FIGURE 7

DISINTERMEDIATION AND RESIDENTIAL CONSTRUCTION 
and tax rates remained low by today's standards until world war II. After the great increase instituted to firance the war, tax rates have fallen only slowly during the post-war period. In addition, the effect of inflation over time has been to lower the real income level associated with the higher marginal tax rates. 6.1

More importantly, however, because the income tax applies to nominal asset returns - including gains in prices that merely keep pace with inflation, and whatever premium nominal interest rates include to compensate lenders for the erosion in the real value of their principal - the faster average rates of inflation in recent years have increasingly magnified the associated tax distortions. Given the tax deductibility of nominal interest payments, the after-inflation interest rate on long-term borrowirg by medium risk business corporations was negative during ten of the thirteen years 1966-78. Analogously, for an individual investor in the median tax bracket among all American taxpayers, the after-inflation after-tax return on Treasury bills was negative during nine of these thirteen years. Moreover, the presence of deposit interest ceilings has further compounded the effect of taxes and inflation. Not since 1967 have ordinary savings accounts at nonbank deposit institutions returned a positive afterinflation after-tax yield to the investor in the median tax bracket.

As the discussion in sections II and III has already noted, a variety of tax-related effects have influenced individuals' and businesses' asset holding and liability issuing behavior as well as the structure of financial intermediation. Individuals' and banks' preferences for tax-exempt state and local government securities, the post-war emphasis on debt in corporate finance, and the increasing channeling of saving through pensions and other 
tax-exempt or tax-sheltered vehicles are all attributable, at least in part, to the interaction of taxes and inflation. Witin the later post-war years, these effects have also led individuals to restructure their portfolios in yet further ways, shifting from deposit to nonderosit forms of finaricial assets and, even more, from financial assets to houses and other real investments. 62 These and similar distortions, like those due to deposit interest ceilings, have presumably had important effects not just on financial market developments but on economic activity more generally.

\section{The Growth of Government Intermediation and Credit Guarantees}

Another important change that has come about within the post-war period, in part as a direct reaction to the distortions noted above, has been the great increase in the federal government's activities as an intermediary for, and also a guarantor of, private credit. The "off-budget" sponsored credit agencies like the Federal Home Loan Bank System and the Federal Intermediate Credit Bank were in operation before World War II, but the scaje of their lending operations was small. As of 1946, all of these agencies combined held only about $\$ 2$ billion of assets, the majority of which consisted of agricultural loans, and they owed only $\$ 2$ billion of liabilities. The focus of these agencies' activity turned more toward support for homebuilding after the Federal National Mortgage Association began its lending operations in 1955, but as late as 1960 , when their combined assets had reached $\$ 11$ billion, their total agricultural credit outstanding still exceeded their total housing credit. Only in the 1960s and 1970s, when the interaction of deposit interest rate ceilings with rising nominal interest rates led to the introduction of large-scale support for housing, did government financial intermediation begin to increase rapidly. 
Table 22 presents data, comparable to that given above for other groups of intermediaries, for the assets of the federally sponsored credit agencies and also the even more recent mortgage "pools" like the Government National Mortgage Association and the Federal Home Loan Corporation. Government sponsored intermediation has grown rapidly, not just absolutely but in relation to gross national product, and by 1978 these intermediaries held more than one-fifth of all outstanding home mortgages and nearly twofifths of all outstanding farm debt. Moreover, the total housing credit advanced by these intermediaries, which has grown especially rapidly since the onset of periodic disintermediation in the mid 1960s, includes not anly direct purchases of mortgages but also Federal Home Loan Bank advances to savings and loan associations, so that the effective amount is even grsater. Given its pattern over time, in the absence of this support ever the cyclicality of homebuilding shown in Figure 7 would presumably have been rore severe. Federally sponsored intermediaries accounted for $45 \%, 48 \%$ and $32 c_{s}$ of the total net extensions of single-family home mortgage credit in the high disinternediation years 1969, 1970 and 1974, respectively. 63

Federally sponsored intermediaries conduct theix business much iike private intermediaries, acquiring financial assets on either a loar or purchase basis, and in turn issuing their own liabilities. There are at least two important differences, however. One is that government intermediaries do not operate subject to the profit motive alone. While they pursue a profit objective, they do so within the limitations imposed by their charter to support areas of economic activity designated by Congress as public policy priorities. ${ }^{64}$. The other key difference is that the liabilities of the mortgage pools and some of the sponsored credit agencies are directly 
Table 22

Assets of U.S. Sponsored Credit Agencies and Mortgage Pools

Combined Financial Assets

$\begin{array}{lll}\text { Combined Financial Assets } & \text { Housing } \\ \text { Total } & \text { Mgencies } & \text { Mortgage Pools } \\ \text { Percent of GNP } & \text { Loans to } \\ \text { Agriculture }\end{array}$

1946-1950

1951-1955

$1956-1960$

1961-1965

$1966-1970$

1971-1975

$1976-1978$

1951-1955

$1956-1960$

1951-1965

$1966-1970$

1971-1975

1976-1978

$\begin{array}{lll}1.0 & 1.0 & 0.0 \\ 1.1 & 1.1 & 0.0 \\ 1.8 & 1.8 & 0.0 \\ 2.5 & 2.4 & 0.1 \\ 3.7 & 3.4 & 0.3 \\ 6.3 & 4.9 & 1.4 \\ 8.8 & 5.4 & 3.5\end{array}$

0.2

0.7

0.0

0.0

0.1

0.3

0.6

0.8

1.1

1.4

1.8

2.2

Percent of Total Combined Financial nssets

Notes: Data are averages of yearend amounts, as percentages of annual gross national product and as percentages of annual total assets.

Detail may not add to totals because of rounding.

Source: Board of Governors of the Federal Reserve system. 
guaranteed by the federal government and accordingly pay interest geared to that on federal government securities. Hence government intermediation also provides some degree of subsidy in the form of access to less expensive (because less risky, by virtue of the guarantee) credit. 65

The federal government's role as a creait guarantor is not limited to the financial intermediation that it sponsors. Deposit insurance, for example, constitutes the most prevalent form of government-sponsored guarantee provided for a fee. Other familiar government-sponsored agencies providing guarantees for a fee include the veterans Adninistration, the Federal Housing Authority, the overseas Investors Protection corporation, the Security Investors protection Corporation, and most recently the Pension Benefit Guarantee Corporation. The federal government has also sponsored large-scale loan guarantee programs for diverse borrowers ranging from college students and small businesses to the Lockheed and chrysler Corporations and New York City. In all, the government's 1978 outstanding credit and credit guarantees - including direct loans, formally guaranteed loans, and other loans by federally sponsored lenders - totaled $\$ 440$ billion in comparison to $\$ 626$ billion of direct federal debt obligations outstanding. In adiation, the amounts of deposits insured by the FDIC and the Federal Savings and Loan Insurance Corporation were $\$ 761$ billion and $\$ 401$ billion, respectively, in 1978 .

The post-war growth in the American economy's reliance on federal government intermediation, deposit insurance, and other credit guarantees has probably been to a great extent a counterpart of the government's waning role as a direct borrower. Given the substantial decline (relative to nonfinancial activity) that has occurred in the federal government's outstanding debt, and the corresponding increase in the outstanding debt of private non- 
financial borrowers, the financial markets have increasingly attempted to make private obligations more acceptable to the economy's ultimate wealth holders by converting them into government obligations via government insurance and credit guarantees. Along with the increase in private finoncial internediation, the growth of government credit guarantees broadiy defined including some that are merely implicit - have enabled the American financial system to absorb the iarge post-war shift in the public versus private mix of direct primary debt.

\section{The Evolution of Monetary Policy}

Finally, one of the most important, and importantly changing, aspects of the federal government's role in the American financial markets during the post-war era has been the monetary policy carried out by the Federal Reserve System. The changes since world war II in the method of conducting monetary policy, in the effect of monetary policy on the American econory, and in the perceptions of monetary policy held by financial market participants häve all been profound.

Although monetary policy developments have been fundamental to the interaction between the American finarciaj. markets and nonfinancial economy, a detailed quantitative analysis of the macroeconomic effects of post-war monetary policy lies beyond the scope of this essay. ${ }^{66}$ Nevertheless, an essay on post-war changes in the financial markets would be incomplete without some attention - albeit at the qualitative level - to how monetary policy has evolved over these years.

The Federal Reserve System, created by Congress in 1914 as America's first central bank since the 1830s, has responsibility for maintaining the currency and also for the implementation of monetary policy, which along 
with fiscal policy has constituted one of the two principal engines of government macroeconomic influence durjing much of this century. As an historical matter, it is interesting to note that the macroeconomic objetives universally associated.with monetary policy in the post-war exa - and especially the objective of maintaining price stability - received no mention by Congress in the original 1913 Federal Reserve Act. Instead, prompted by the recurrent series of financial crises and panics, most recently in 1901, 1907 and 1913, Congress charged the new Federal Reserve System with the more direct task of preserving stability in the financial markets. More specifically, with the contractionary economic effect of the recent financial panics in mind, Congress instructed the Federal Reserve "to furnish an elastic currency" - exactly the opposite of the antiinflation objective widely associated with monetary policy, and viewed by many people as the chief desideratum of monetary policy, today.

The use of monetary policy to achieve broader nacroeconomic objectives evolved slowly and cautiously during the pre-war years, as economists and Federal Reserve officials gradually came to understand the working of open market operations, now the most important tool of monetary policy but not even contemplated as such in the Federal feserve Act. The establishmert in 1923 of what sibsequently developed into today's Federal open Market Committee led temporarily to an increasing emphasis on open market operations and macroeconomic objectives, but the confusions of the depression and the associated international monetary problems then arrested the development of the monetary policy mechanism. During world war II the Federal Reserve facilitated the financing of the huge increase in public debt noted above by supporting the prices of Treasury securities. After the war the reluctance to impose losses on investors who had financed the war effort led to a continuation of the bond price supports, thereby precluding active use of 
monetary policy for a further half-decade.

The first major post-war change in the postlure of American monetary policy came in 1951, when the Treasury-Federal Reserve Rccord relieved the central bank of its wartime obligation to peg long-term interest rates. Monetary pol.icy then assumed the macroeconomic role that it has played ever since. Even so, interest rates, especially short-term rates, remained relatively low during much of this period (see again Figure 2), and the Federal Reserve on balance followed the half-restrictive, half-accommodative policy subsequently known as "leaning against the winc." More specifically, the Federal Reserve primarily keyed its open market operations in the ver $\ddot{y}$ short run to the net frẹe reserve position (that is, excess reserves less borrowed reserves) of the commercial banking system. The theory of open market operations underlying this operating strategy - which was based on the relation between sources and uses of bank reserves, and on the assurption of banks' interest inelastic demand for excess reserves and reluctance to borrow at the discount window - implied that net free reserves measured banks' willingness to extend loans and create deposits, and hence measured the effect of monetary policy in stimulating or retarding nonfinancial economic activity. In addition, net free reserves appeared to constitute the perfect "money market" variable - a close proxy for market interest rates (given the level of the Federal Reserve's own discount rate), yet not itself an interest rate and hence not a contradiction of the Accord.

For several reasons financial market participants during the 1950 s and even the early 1960 s did not attach to monetary policy the great importance that they have associated with it in more recent years. The "go-slow" consensus economic philosophy of the Eisenhower years - which Congress never actively opposed, even unaer the Democratic majorities of the second half of the decade - was broadly consistent with the "sound money" ethos traditionally 
associated with centra]. banking as well as the more specific "leaning against the wind" policy, which served to dampen cyclical fluctuations of market interest rates as wej.I as to keep them low on average. In addition, although most economists had favored the Accora freeing monetary policy, much of the popular thinking of the 1950s emphasized the newfound importance of fiscal policy.

Several changes occurred thereafter, however, that not only heightened market participants' awareness of monetary policy but also changed how monetary policy has worked. The emergence of a "guns plus butter" policy, as the Great Society program and the Vietnam War effort peaked simultaneously, had the support of Congress but appeared to be running afoul of the Federal Reserve as interest rates climbed steadily beginning in 1965. Restrictive monetary policy was a major factor, and visibly so, in the macroeconomic policy environment from 1966 on, in part because of the increased sensitivity of the financial markets to interest rate levels as they interacted with the deposit rate ceilings (see again Figure 7). After 1969 the acceleration of price inflation raised new questions about the relative priority of full employment and price stability in macroeconomic policy making, and the business recessions of 1969-70 and especially 1973-75 placed monetary policy in the midale between the unprecedented double-digit price inflation and the highest unemployment rate of the post-war era. Monetary policy had gradually moved from off stage to on, and then to the center.

Another source of the increasing attention focused on monetary policy during the second half of the post-war period has been a change of attitudes toward fiscal policy. When it emerged during the 1960 s that an occasionally 
flexible fiscal poljoy was not as sufficient as many people had hoped as a "cure" for business fluctuations, the ferception of the potential of monetary policy expanded to fill the apparent need. $f_{1}$ s is usual in such. situations, once opirion began to change it probably went too far in the opposite direction. In the context of an already somewhat polarized economic policy environment, monetary policy therefore became simultaneously the hope of those who opposed whatever they believed to be the current stance of fiscal policy, as well as the target of those who supported that stance but were dissatisfied with the apparent results. Noreover, the question of the fiscal-monetary balance, and therefore the coordination of fiscal and monetary policies, also emerged as issues of some import. Matters of timing came to be perceived as relevant too, as evidence accumulated on the lags associated with the effects of policy actions. Most economists continued to believe that the "outside" lags with which monetary policy influences business activity were longer than the corresponding fiscal policy lags, but the Federal Reserve's compact decision structure shortened the "inside" lag of monetary policy in comparison with the cumbersome Congressional committee process involved in taking fiscal actions.

At the same time, questions arose about the operating methods used to conduct monetary policy per se. Most of the attention centered on the shortrun policy of setting the banking system's free reserve position, and then after 1961 on the corresponding short-run policy of setting a short-term interest rate. The essence of the debate was whether this operating method in fact constituted only a short-run guide for open market operations aimed at broader objectives or, instead, had developed into a system of false 
beacons for policy over the longer run. The main point was that it was not. appropriate simply to regard monetary policy as steacy or changing because market interest rates (or free reserves) were rixed or moving. What mattered was instead the relationship between observed interest rates and scmeting else - something that was at best difficult to determine: Events playea a part here, too, as the acceleration and increasing volatility of price inflation rendered the inference of a "real" market rate of interest ever more difficult. To the extent that allowing for price expectations was basic to interpreting observed (nominal) interest rates as "indicators" of the likely effect of monetary policy on nonfinancial economic activity, calculating such corrections was becoming ever more difficult.

At the beginning of the 1970s, therefore; the Federal Reserve shified the strategy of its monetary policy yet again - this time to an emphasi. on quantitative measures of commercial banking activity in general, and on the narrowly defined Ml money stock in particular. In the late 1960 s the Federal Reserve had experimented with a "proviso" approach, according to which short-rur open market operations pursued a stated interest rate objective provided that doing so did not cause some aggregate measure to deviate from a predetermined range. In 1970 the Federal Reserve finally adopted an operating strategy based explicitly on monetary targets. The directives governing the conduct of open market operations continued to specify a narrowly constrained short-term interest rate (the federal funds rate), but with the clear understanding that this practice was in large part meant to achieve the targeted rate of monetary growth. Although these directives typically specified target ranges for the growth of several monetary aggregates, as well as commercial bank credit, in practice the focus 
of policy through the time of writing seems to have been primarily on the narrow money stock. 67

The Federal Reserve's monetary targets strategy has subsequently evolved into a fairly well-defined two-stage procedure. First, at the "strategy" level, about once per quarter the Federal Reserve translates its ultimate policy aims (in terms of the economy's growth, employment, price stability, and so on) into a set of desired growth rates for the monetary aggregates over the next year. Because it will choose a new set of desired one-year growth rates three months later, however, only the first quarter of this one-year extrapolation is of direct operational relevance. Second, at the "tactics" level, within the quarter the Federal Reserve determines how best to manipulate the instruments over which it can exert close control (such as nonborrowed bank reserves, or a short-term interest rate) so as to cause the designated monetary aggregates to move in tho specified way. In practice the federal funds rate typically served in this instrument role until 1979, when the Federal Reserve initiated a new experiment using the growth of bank reserves as its short-run operating guide. Although the Federal Open Market Committae, which has responsibility for these decisions, meets formail. only once a month, it also occasionally uses telephone conferences to make within-month adjustments in the instrument setting aimed at achieving the desired monetary growth, subject only to the need to avoid undue instability in the money market. Apart from occasional variations, the Federal Reserve has essentially continued to pursue its monetary targets operating strategy along these lines through the time of writing.

In part as a result of the new strategy of open market operations implemented during the 1970s, the short-run volatility of market interest 
rates sh:arply increased (see again Figure 2). These wider interest rate fluctuations in turn have been the source of mary of the developments discussea earlier in this essay. Together with the ever higher average level of interest rates during the second half of the post-wer pexiod, they have heightened the awareness of monetary policy among nearly all participants in the financial markets. In addition, along with dissatisfaction with macroeconomic outcomes in the 1970s, they have spurred congress to institute regular "oversight" procedures requiring the Federal Reserve periodically to report its current monetary growth targets tinrough the relevant congressional comittees. The practical ability of Congress to supervise the Federal Reserve's monetary policy in any effective sense, however, appears to he dubious at best. 68

Finally, a feature of American monetary policy that has also changed several times since World war II has been the degree of influence associated with international considerations. Before the var international financial matters were often at the heart of Federal Reserve policy making. By contrast, during the "dollar shortage" of the early post-war years American monetary policy was largely free to pursue domestic objectives without much regard for international considerations, and the relatively conservative posture of monetary policy (and fiscal policy) during much of the 1950 s posed no threat to the country's already strong currency anyway. ${ }^{69}$ After the balance of payments had become a major problem in the early 1960s, however, the Federal Reserve began at times to take monetary policy decisions with an eye to their international ramifications. Since then the international constraint on monetary policy making has strengthened and then waned several times. Somewhat surprisingly, although the American role in the international monetary system became a major focus of attention in the early 1970s, with the exchange 
rate realignment and suspension of dollar-gold convertibility in 1971 and the move to floating exchange rates after 1973 , American monetary policy primarily emphasized domestic objectives during these years. By contrast, in the late 1970 s (and through the time of writing), despite inconvertibilityr and floating rates international considerations appear to have exerted more influence over monetary policy than at any time since the early $1960 \mathrm{~s} .70$ 


\section{v. Summary and Concluding Comments}

This essay has documented three major developments that have dominated the American financial markets since World war II.

First, the nonfinancial econom has increasingly relied on privates debt financing. At the war's end there was much government debt but little private debt outstanding. Since then both nonfinarcial businesses and individuals have greatly increased their indebtedness, while the federal government has sharply reduced its indebtedness, in comparison to the economy's nonfinancial activity. The sustained rise in private indebtedness has represented in part a return to pre-war practices after the aberration of the depression and war years, and in part the establishment of new norms for indebtedness in relation to incomes. Perceptions of enhanced economic prosperity and stability, greater tax incentives to debt finance under conditions of accelerating price inflation and rising nominal interest rates, increased holdings of physical assets, and the relative deciine in governmentissued debt per se have probably played some part in accounting for the large relative increase in the nonfinancial economy's private debt.

Second, the economy has increasingly relied on financial intermediaries to hold the claims issued by nonfinancial borrowers. Individuals as well as other nonfinancial investors have allocated a growing share of their portfolios to claims on financial intermediaries, rather than direct claims on nonfinancial borrowers. Even in the holding of corporate equities, the one area traditionally dominated by individual ownership, intermediaries have begun to play a more substantial role. Nonbank deposit intermediaries, including especially savings and loar associations, and private and public sector pension funds have figured prominently in the continuing overall 
post-war rise in financial intermediation. This increasing degree of financial intermediation has facilitated the increased debt financing of private nonfinancial borrowers and, together with a series of financial innovations, has also helped to treal down barrjers and frictions interfering with efficient allocation of the econom's financial resources.

Third, in contrast to its declining role as a direct borrower, the federal government has in other ways become more of an influence in the financial markets. The government has increasingly served as an insurer and guarantor of, and an intermediary for, private claims. Federal deposit insurance, irstituted shortly before the war, importantly changed the character of private intermediation, and other forms of government credit guarantees have proliferated subsecuently. Eederally sponsored credit agencies, and more recently mortgage pools, have supplemented private intermediation. Goverrment regulation of the financial markets has also increased in both scope and effect, and market participants have come to attach ever more importance to monetary policy actions as well.

Finally, it is important to re-emphasize that these three post-war developments - the rise of the private debt econory, the increasing degree of. financial intemediation, and the growing role of the federal governmerit are not independent phenomena. These three ongoing processes constitute different but closely related facets of the same overall pattern of American financial evolution. Because of the differing risk and liquidity characteristics of public versus private securities, the post-war shift from public to private debt has increased the economy's need for financial intermediation, and the growth and development of that intermediation have in turn facilj.tated the successful issuance and absorption of ever greater amounts of private debt 
relative to nonfinancial activity. Similarly, in place of airect governmentissued debt, the federal govemment has indirectly transformed private debt into its own on an increasing scale through a combination of guarantees and federally sponsored intermediation. On balarce, over thirty-five years the most important post-war changes in the Anerican financial markets have largely been parts of the same consistent. story. 


\section{Footnotes}

* This essay is a part of the National Bureau of Economic Research project: on Post-War Changes in the American Economy. I am grateful to Christopher Piros and Michael Burda for research assistance; to James Dueserberry, John Lintner, Sanford Rose, Willịam Silber, Stephen Taylor and James Tobin for helpful discussions and comments on an earlier draft; and to the National Bureau and the Alfred P. Sioan Foundation for research support.

1. See Gordon's essay in this volume for a comprenensive treatment.

2. Table 1 is in part adapted from Baily (1978).

3. Moreover, the use of annual data for the first seven downturns shown in Table 2 importantly understates the peak-to-trougi decline of real gross national produst in comparison to that shown using quarterly data for the six post-war downturns.

4. Kindleberger (1978) provided a lively review of the international propagation of economic disturbances.

5. Perry (19?7), Jorgenson (1978) anä Perloff and wachter (i979) documented this shift and offered alternative explanations.

6. Debt issued by nonfinancial borrowers is similar to the concept of "primary securities" introduced by Gurley and Shaw (1960).

7. The data shown here include only those liabilities classified as "credit market debt" in the Federal Reserve Board's flow-of-funds accounts. The debt of the federal government therefore excludes currency and bank reserves but includes the Federal Reserve System's holdings of U.S. 
government securities $(\$ 147.8$ billion and $\$ 118.6$ billion, respectively, as of yearend 1978). For state and local governments, households, and unincorporated ronfinancial businesses, credit market debt in each case constituted $95 \%$ or more of all liabjuties outstanding as of yearend 1978; for nonfinancial business corporations, yearend 1978 total liabilities consisted of $71 \%$ credit market liabilities, $24 \%$ trade debt (almost all owed to each other), and $5 \%$ other liabilities.

8. It is not appropriate to include foreign debt in an analysis of these data from the perspective of the U.S. economy's liability issuing behavior. By contrast, if there were some assurance that debt issued by foreign borrowers in U.S. markets remained in the portfolios of U.S. investors, then it would be appropriate to include that debt in an analysis from the perspective of the U.S. economy's asset holding behavior. (The caveat, of course, would apply as well to debt issued in the U.S. markets by U.S. borrowers.)

9. The peak debt/GNP ratio during 1918-78 occurred in 1933, the trough year of tine depression. In addition, much of the household and business debt nominaily outstanding during the depression was of questionable actual value.

10. During 1953-1978 the U.S. debt/GNP ratio has been more stable than the money/GNP ratio. This statement is true regardless of whether one uses annual or quarterly data, either unadjusted or detrended, with money measured as either M1 or M2; see Friedman (1979a).

11. See Friedman (1979a) for a discussion of each of these three behavioral hypotheses and a look at some pertinent post-war evidence. 
12. The U.S. government's debt increased from only $\$ 1.2$ billion in 1916 , the year in which the united states entered the war, to $\$ 25.6$ billion in 1919, the year in winch the war ended.

13. Apart from a discrepancy due to inadeguacies of statistical reporting, the total sources of funds shown in Table 5 is equal to the total uses of funds shown in Table 4.

14. According to U.S. Department of Cormerce estimates, reported depreciation allowances understated corporations' true capital consumption by some $\$ 2-4$ billion annually during 19:6-61, then overstated it by about the same amount during 1962-73, and since 1974 has understated it again by an increasing amount ( $\$ 13$ billion in 1978). See Feldstein and Summers (1979) for an analysis of the relation between allowable depreciation and true capital corsumption under condj.tions of price inflation.

15. During 1971-76, the years of the equity bulge, public utility companies accounted for $46 \%$ of total gross offerings, and preferred shares accounted for $29 \%$ of total gross offerings. (These data, from the Securities and Exchange Comission, are not available on the net basis used in Table 5.)

16. For an analysis of this issue see Feldstein (1976) and Feldstein et. al. (1978). The more basic point that the corporate tax structure favors debt over equity finansing has long been familiar; see, for example, Modigliani and Miller (1963).

17. Long-term debt, with a maturity of over one year, is measured approximately as bonds, multi-family and commercial mortgages, and $40 \%$ 
of bank loans. Short-term debt is all other credit market borrowings, including mostly finance company loans, comnercial paper, and the remainder of bank loans.

18. The rise in short-tem indebtedness (wish reached 25.7 of creäit market debt as of yearend 1978) still seems small in comparison with the attention it has received. Moreover, even the small increase that has occurred may be only an illusion if, as seems likely, an increasing share of bank lending is actually intermediate-terti. The much discussed notion of declining corporate liquidity is captured much better by the relationships among both liabilities and assets. (See again the data in Table 4 on funds used to acquire financial assets.) The yearend ratio of the corporate sector's liquid assets to its shortterm liabilities has fallen from .86 in 1946 to .68 in $1950, .48$ in 1960, .26 in 1970 and a low point of .25 in 1973; after recovering to .34 in 1976, as a consequence of the severe 1973-75 recession, the ratio has fallen again to .27 in 1978.

19. Hendershott and Hu (1979) have documented the growing after-tax incentive for individuals' mortgage borrowing to finance home ormership in recent years, even for those in marginal tax brackets as low as $30 \%$. A similar conclusion holds for consumer credit, although here low tax bracket individuals account for more of the borrowing.

20. Apart from a discrepancy due to inadequacies of statistical reporting, the total sources of funds shown in rable 8 is equal to the total "investment" uses of funds shown in Table 7.

21. Although installment credit constituted only about one-half of total 
consumer credit outstunding in the early post-war years, it has so dominated consumer borrowing that, as of yearend 1.978, households owed $\$ 276$ billion of installment credit and only $\$ 64$ billion of other consumer credit.

22. Since the early 1960 s the most rapidly growing expense item of state and local governments has been contributions to their employees' pension funds; see Munnell and connolly (1975) for a review of this experience. The growth of these pension funds has itself been an important development, on which section III below focuses.

23. To avoid confusion it is worth noting explicitly that the general funds of state and local governments have been in surplus in the 1970s. Since their pension funds also run a large current surplus, the statelocal government sector has been heavily in surplus on a consolidated basis throughout the post-war period.

24. Because of the enormous size of the U.S. markets, however, especially in comparison with specific foreign markets, what represents only a small part of lending here may often play a sizeable role in meeting the nesds of particular foreign borrowers.

25. See Solomon (1977) for a description of the capital controls program and a discussion placing it in the context of the U.S. economy's postwar foreign economic policy.

26. Remaining barriers to foreign securities issues in the U.S. market include the withholding tax on interest and dividends paid to foreigners and disclosure requirements of the Securities and Exchange Commission. 
27. Because of the cyclicality of transfer payments and the overall weakness of the U.S. economy in the 1970s, the data shown iri Table 11 sjightiy overstate the trend increase in both trarsfers and total federal. expenditures in relation to gross national product. See Break's essay in this volume for a comprehensive review of post-war trends in federal spending.

28. In 1978, the fourth year of the economic expansion, the (calendar year) federal deficit was $\$ 28$ billion, or $1.3 \%$ of gross national product.

29. During this same period the Federal Reserve System was trying, via its "Operation Twist," to shorten the mean maturity of the federal debt held by public investors. As Table 12 shows, the debt management policy predominated. A number of researchers subsequently attempted to analyze the effects of Operation Twist as if it were not offset by dejt management policy; see, for example, Modigliani and Sutch $(1966,1967)$. In light of the prevailing debt management policy, it is not surprising that such efforts were unsuccessful.

30. See Goldsmith (1958, 1969) and Gurley and Shaw (1960) for an analysis of the pre-war experience.

31. The interesting question of cause and effect. between these two developments lies beyond the scope of tinis essay.

32. The data plotted in Figure 4 and used aiso in Table 13 below refer only to financial assets and hence exclude nonfinancial assets like houses and consumer durables. As of yearend 1978 households' nonfinancial assets, valued at replacement cost, totaled $\$ 2.8$ trillion (of which $\$ 1.5$ trillion was residential real estate) in comparison to $\$ 4.8$ trillion of financial assets. The available current-value data on nonfinancial 
asset holdings are understandably weak.

33. Moreover, these data overstate households' direct equity holdings in that they do not separate holdings via mutual funds, which grew from an average $2 \%$ of total equity holdings in $1946-50$ to $7 \%$ in 1971-75.

34. Feldstein (1974), for example, derived a large estimate of Social Security "wealth" (defined as the present discounted value of expected future benefits) and found evidence of a significant impact of social Security on private saving behavior. Although this work and the literature that has followed it have emphasized effects on total saving behavior, there is no reason to expect the composition of asset holding to remain invariant.

35. Some of the best known examples of this thinking were Greenough (1951) and Advisory Committee (1969).

36. Lintner (1975), Modigliani and cohn (1979) and Feldstein (1979), among others, have provided analyses of the failure of equity returns to keep pace with inflation.

37. Table $14 \div$ is adapted from Bodie (1979) and is based on updated annual data compiled by Ibbotson and Sinquefield (1977): see also Bodie (1976). See Cagan (1974) for a more detailed examination of data over a longer time period and for cross-country comparisons.

38. See Hartman (1978) for a review of the participation of foreign investors in the U.S. financial markets. A distinction documented by Hartman is that, within the category of long-term portfolio (as opposed to direct) investments, foreign investors have mostly bought U.S. equities while U.S. investors have mostly bought foreign debt securities. 
39. Funds generated internally and retained by corporate businesses also represent a form of investment by the holders of equity shares in those corporations. Given the large household ownership of equities, including retained earnings in the data shown in Table 12 would greatly increase the share of funds "acivanced" by nonfinancial investors but would still leave intermediaries as the direct source of well over half of the total.

40. Much of this literature has followed the lead of Gurley and Shaw (1960).

41. Following Glass-Steagail, commercial banks no longer engage in investment banking or broker-dealer activities for publicly offered corporate securities, although they do so for pubiic sector securities, and in recent years they have been increasingly involved ir: arranging direct placements of corporate securities. In adaition, the trust departments of commercial banks continue to be the largest single fáctor in private asset management.

42. See Fellner and Larkins (1976) for a discussion of the stability of $M 2$ velocity, and Friedman (1979b) for a corresponding discussion for bank credit.

43. The work of Friedman (1959) and Friedman and Schwartz (1963) explained the downward pre-war trend in M2 velocity by emphasizing the role of money as a luxury good.

44. Banks' holdings of Treasury securities were essentially flat from 1946 until the swelling of the federal deficit occurred in 1975, so that banks' portfolios of municipals have exceeded their portfolios of Treasuries ever since 1969. Except for 1974-76, all of the growth in 
banks' holdings of federal government debt has consisted of federa? agency securities.

45. See Goldfeld $(1973,1976)$ for a review of the post-war evidence on money demand behavior.

46. See Rhoades (1976) for a summary of changes in banking structure following the 1970 amendments.

47. In Table 18, however, the respective size of the three groups is indicated by their total assets because of the lack of historical data on pension funds' liabilities.

48. See Weiss (1976) for a review of the ERISA legislation and its impact.

49. Tepper and Affleck (1974) and Oldfield (1976), among others, have investigated the nature of this underfunding. Although corporations are now required to report (as a footnote to the balance sheet) the difference between pension assets and liabilities for vested benefits, there is no easy way to discover the liability for nonvested benefits.

50. See again Munnell and connolly (1976).

51. Silber (1977), for example, has analyzed liquidity provided by markets as an alternative to liquidity provided by intermediaries.

52. See Branson's essay in this volume for a comprehensive treatment.

53. Silber (1975) has developed a theory of financial innovation. For discussions of the impact of specific recent financial innovations, see, for example, Lieberman (1977), Porter et al. (1979) and Lombra and Kaufman (1978). 
54. Tobin (1963), for example, called on the government to issue such an instrument long before the major acceleration of inflation. More recently, researchers have sought to discover why the private markets have not provided it; see, for example, Fischer $(1975,1979)$.

55. See, for example, Moßigliani and Lessard (1975).

56. See Caves' essay in this volume for a comprehensive treatment.

57. Data on bank failures are available from Friedman and Schwartz (1963) and successive issues of the FDIC Annual Report.

58. For analyses of this issue see, for example, Maisel (1979).

59. The federal government's most ambitious post-war effort to restructure the investment banking industry failed, however, when the government lost the antitrust suit it brought against seventeen leading investment banking firms (U.S. v. Morgan et al.) in 1951.

60. An anomaly of these ceilings is that mutual institutions which are in principle owned by their depositors - including savings and loan associations, mutual savings banks and credit unions - are prohibited from fully distributing earnings to their owners. Earnings above the ceiling rate merely accumulate unless the institution converts to a stock organization (as is legal for savings and loans), in which case they become a windfall to the new owners.

61. Congress has repeatedly adjusted the brackets, but on balance these adjustments have had sufficient redistributive elements to reduce the real income level to which the higher marginal rates apply.

62. Kane (1980), for example, has documented the substantial shifts in individuals' asset holding.since the early 1960s. 
63. It is possible, however, that the mortgage market receives less as a net addition to available funds than all of the credit provided by the sponsored credit agencies and mortgage pools if they in turn sell their securities to investors who would othervise have held deposits in thrift institutions. See, for example, the analysis of this question in Jaffee and Rosen (1979).

64. It is important not to draw this distinction too firmly, however. For example, savings and loan associations are constrained to hold at least $82 \%$ of their asset portfolios in residential mortgages (or other qualified assets). Also, as the discussion above notes, in the presence of deposit interest ceilings limiting the pay-out of earnings to holders of deposit shares, it is not clear what role the profit motive plays in savings and loans' portfolio decisions.

65. See Penner and Silber (1973) for an analysis of the subsidy implicit in federal credit programs.

66. See Gordon's essay in this volume. For more detailed accounts of postwar monetary policy, see Friedman and Schwartz (1963), Brunner and Meltzer (1964), Guttentag (1966), Bach (1971), Brimmer (1972) and Poole (1975). Parts of what follows draw on Friedman $(1977,1978)$.

67. Although some observers have alleged that the Federal Reserve's commitment to the monetary growth targets has been largely rhetorical, a steady accumulation of evidence shows that the observed movement of the money stock in relation to its targeted growth path has become a major determinant - on some evidence, the dominant one - of short-run monetary policy operations. De Rosa and Stern (1975), Feige and McGhee (1979) and Lombra and Moran (1979) have all found evidence to this effect. 
68. Pierce (1978) and Roberts (1978) have both assessed this effort and drawn essentially negative conclusions.

69. Concerns about the dollar's external position first arose in conjunction with the government's $\$ 12$ billion deficit in 1958 - a peacetime record at the time, and equal to nearly $3 \%$ of the gross national product (a relative size not again reached until the $1973-75$ recession).

70. Sec again Solomon (1977) for a detailed account of the role of international factors in U.S. monetary policy making. 


\section{References}

Advisory Committee on Endowment Management. 1969. Managing educationa? endowments. New York: Ford Foundation.

Bach, G.L. 1971. Making monetary and fiscal policy- Washington: The Brookings Institution.

Bailey, Martin Neil. 1978. Stabilization policy anả private economic. behavior. Brookings Papers on Economic Activity, 11-50.

Bodie, Zvi. 1976. Commor stocks as a hedge against inflation. Journal of Finance $31: 459-470$.

- 1979. Purchasing-power annuities: Financial innovation for stable real retirement income in an inflationary environment. Mimeographed, National Bureau of Economic Research.

Brimer, Andrew F. 1972. The political economy of money: Evolution and impact of monetarism in the Federal Reserve System. American Economic Review, Papers and Proceedings 62: 344-352.

Brunner, Karl, and Meltzer, Allan H. 1964. The Federal Reserve's attachment to the free reserve concept. United States House of Representatives, Committee on Banking and Currency, Subcommittee on Domestic Finance, 88th Congress, 2nd Session.

Cagan, Phillip. 1974. Common stock values and inflation - the historical record of many countries. New York: National Bureau of Economic Research. 
DeRosa, Paul, and Stern, Gary H. 1977. Monetary control and the federal funds rate. Journal of Monetary Economics 3: 217-230.

Feige, Edgar L., and MCGhee, Robert. 1979. Has the Federal Reserve shifted from a policy of interest rate targets to a policy of monetary aggregate targets? Journal of Money, Credit and Banking $11: 381-404$.

Feldstein, Martin S. 1974. Social security, induced retirement and aggregate capital formation. Journal of Political Economy 82: 905-926. - 1976. Inflation, income taxes, and the rate of interest: A theoretical analysis. American Economic Review 66: 809-820. - 1979. Inflation, tax rules, and the stock market. Mimeographed, National Bureau of Economic Research.

Feldstein, Martin S., Green, Jerry, and Sheshinski, Eytan. 1978. Inflation and taxes in a growing ecoromy with debt and equity finance. Journal of Political. Economy 86: s53-s70.

Feldstein, Martin S., and Summers, Lawrence H. 1979. Inflation and the taxation of capital income in the corporate sector. National Tax Journal 32: 000-000.

Fellner, William, and Larkins, Dan. 1976. Interpretation of a regularity in the behavior of M2. Brookings Papers on Economic Activity: 741-761. 
Fischer, Stanley. 1975. The demand for index bonds. Journal of Political Economy 83: $509-534$.

- 1979. Corporate supply of index bonds. Mimeographed, National Bureau of Economic Research.

Friedman, Benjamin M. 1977. The inefficiency of short-run monetary targets for monetary policy. Brookings Papers on Economic Activity: 293-335.

- 1978. Public disclosure and domestic monetary policy. In Erb, Richard D., ed., Federal Reserve policies and public disclosure. Washington: American Enterprise Institute. - 1979a. The relative stability of money and credit 'velocities.' Mimeographed, Harvard University. - 1979b. Money and credit targets under the proposed redefinitions of the monetary aggregates. Mimeographed, Harvard University.

Friedman, Milton. 1959. The demand for money: Some theoretical and empirical results. Journal of Political Economy 67: 327-351.

Friedman, Milton, and Schwartz, Anna Jacobson. 1963. A monetary history of the United States 1867-1960. Princeton: Princeton University Press.

Goldfeld, Stephen M. 1973. The demand for money revisited. Brookings Papers on Economic Activity: 577-638. 
- 1976. The case of the missing money. Brookings

Papers on Economic Activity: $683-730$.

Goldsmith, Raymond w. 1958. Financial intermediaries in the Americar. economy since 1900. Princeton: Princeton University Press.

- 1969. Financial structure and development. New

Haven: Yale University Press.

Greenough, William C. 1951. A new approach to retirement income. New York: Teachers Insurance \& Annuity Association of America.

Gurley, John G., and Shaw, Edward S. 1960. Money in a theory of finance. Washington: The Brookings Institution.

Guttentag, Jack M. 1966. The strategy of open market operations. Quarterly Journal of Economics $80: 1-30$.

Hartman, David G. 1978. Long-term international capital flows and the U.S. economy. Mimeographed, Harvard University.

Hendershott, Patric H., and Hu, Sheng Cheng. 1979. Inflation and the benefits from owner-occupied housing. Mimeographed, National Bureau of Economic Research.

Ibbotson, Roger G., and Sinquefield, Rex A. 1977. Stocks, bonds, bills and inflation. New York: Financial Analysts Research Foundation.

Jaffee, Dwight M., and Rosen, Kenneth T. 1979. Mortgage credit availability and residential construction. Brookings Papers on Economic Activity: $333-376$. 
Jorgenson, Dale W. 1978. The role of energy in the U.S. economy. National Tax Journal 31: 209-220.

Kane, Edward J. 1980. Consequences of contemporary ceilings on mortgage and deposit interest rates for households in different economic circumstances. In von Furstenburg, George M., ed., The government. and capital formation. Cambridge: Ballinger.

Kindleberger, Charles P. 1978. Manias, panics, and crashes. New York: Basic Books, Ine.

Lieberman, Charles. 1977. The transactions demand for money and technological change. Review of Economics and Statistics 54 : 307-317.

Lintner, John. 1975. Inflation and security returns. Journal of Finance 30: 259-280.

Lombra; Raymond E., and Kaufman, Herbert M. 1978. Commercial banks and the federal funds market. Economic Inquiry 16: 549-562.

Iombra, Raymond E., and Moran, Michael. 1979. Policy advice and policymaking at the Federal Reserve. Mimeographed, Pennsylvania State University.

Maisel, Sherman J. (ed.). 1980. Risk and capital adequacy in commercial banks. Chicago: University of Chicago Press.

Modigliani, Franco, and Cohn, Richard A. 1979. Inflation, rational valuation and the market. Financial Analysts Journal: 3-23. 
Modigliani, Franco, and Lessard, Donald R., eds. 1975. New mortgage designs for stable housing in an inflationary environment. Boston: Federal Reserve Bank of Boston.

Modigliani, Franco, and Miller, Merton H. 1963. Corporate income taxes and the cost of capital: A correction. American Economic Review $53: 433-443$.

Modigliani, Franco, and Sutch, Richard. 1966. Innovations in interest rate policy. American Economic Review, Papers and Proceedings 56: $178-197$.

- 1967. Debt management and the term structure of interest rates. Journal of Political Economy 75: 569-589.

Munnell, Alicia H., and Connolly, Ann M. 1976. Funding government pensions: State-local, civil service and military. In Funding pensions: Issues and implications for financial markets. Boston: Federal Reserve Bank of Boston.

Oldfield, George S. 1976. Financial aspects of the private pensiors system. Journal of Money, Credit ard Banking 9: 48-54.

Penner, Rudolph G., and Silber, William L. 1973. The interaction between federal credit programs and the impact on the allocation of credit. American Economic Review 63: 838-852.

Perloff, Jeffrey M., and Wachter, Michael L. 1979. A production function-nonaccelerating inflation approach to potential output: Is measured potential output too high? In Brunner, Karl, and 
Meltzer, Allan H., eds., Three aspects of policy and policymaking: Knowledge, data and institutions. Amsterdan: North-Holland Publishing Company.

Perry, George L. 1977. Potential output and productivity. Brookings Papers on Economic Activity: $11-47$.

Pierce, James L. 1978 The myth of Congressional supervision of monetary policy. Journal of Monetary Economics $4: 363-370$.

Poole, william. 1975. The making of monetary policy: Description and analysis. New England Economic Review (March/April): 21-30.

Porter, Richard D., Simpson, Thomas D., and Mauskopf, Eileen. 1979. Financial innovation and the monetary aggregates. Brookings Papers on Economic Activity: $213-237$.

Rhoades, Stephen A. 1976. Changes in the structure of bank holding companies since 1970. Bank Administration 52: 64-69.

Roberts, Steven M. 1978. Congressional oversight of monetary policy. Journal of Monetary Econornics 4: 543-556.

Silber, william L. 1975. A theory of financial innovation. In silber, William L., ed., Financial innovation. Lexington: D.C. Heath. - 1977. The optimum quantity of money and the interrelationships between financial markets and intermediaries. Banca Nazionale del Lavoro Quarterly Review: 87-95. 
Solomon, Robert. 1977. The incernational monetary system 1945-1976: An insider's view. New York: Harper \& Row.

Tepper, Irwin, and Affleck, A.R.P. 1974. Pension plan liabilities and corporate financial strategies. Journal of Finance 23: 15491564 .

Tobin, James. 1963. An essay on the principles of debt managenent. In Commission on Money and credit, Fiscal and debt management policies. Englewood Cliffs: Prentice-Hall.

Weiss, Randall D. 1976. Private pensions: The impact of ERISA on the growth of retirement funds. In Funding pensions: Issues and implications for financial markets. Boston: Federal Reserve Bank of Boston. 